\title{
The Deposition History of the Coversands along the Bree Fault Escarpment, NE Belgium
}

\author{
M. Frechen ${ }^{1}$, K. Vanneste ${ }^{2}$, K. Verbeeck ${ }^{2}$, E. Paulissen $^{3}$ \& T. Camelbeeck ${ }^{2}$ \\ 1 Universität Regensburg, Institut für Geographie, D-93040 Regensburg, Germany \\ Present address: Institut für Geowissenschaftliche Gemeinschaftsaufgaben (GGA), S 3: \\ Geochronology and Isotope Hydrology, Stilleweg 2, D-30655 Hannover, Germany; \\ e-mail: M.Frechen@gga-hannover.de \\ 2 Royal Observatory of Belgium, Avenue circulaire 3, B-1180 Bruxelles, Belgium; \\ e-mail: kris.vanneste@oma.be; koen.verbeeck@oma.be and cam@oma.be \\ 3 Insituut voor Aardwetenschappen, Geomorfologie, Katholieke Universiteit Leuven, \\ Redingenstraat 16 bis, B-3000 Leuven, Belgium; \\ e-mail: etienne.paulissen@geo.kuleuven.ac.be
}

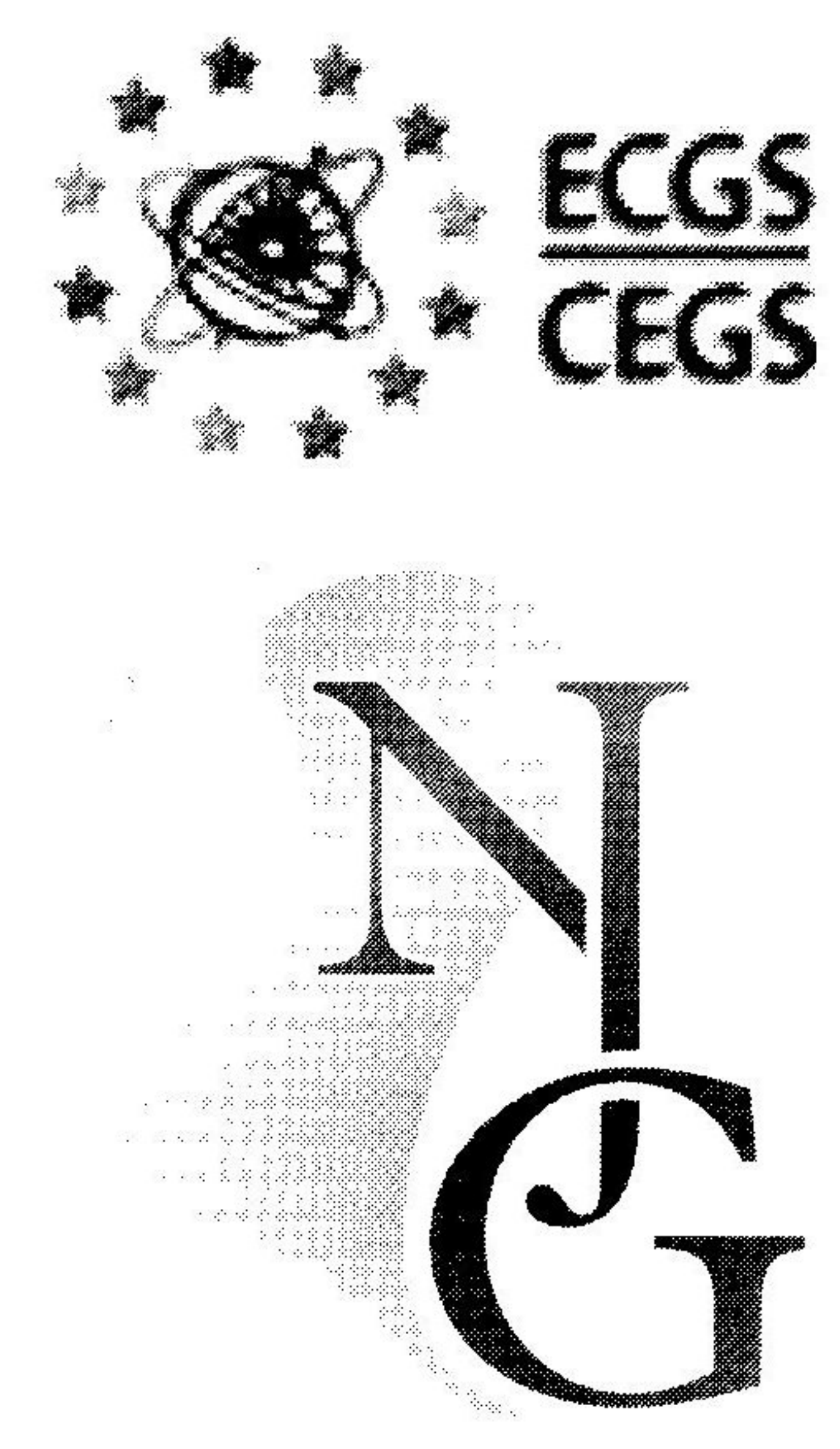

Manuscript received: July 2000; accepted: April 2001

\begin{abstract}
The coversands along the Bree fault escarpment, NE Belgium, were investigated by a combined dating approach including infrared optically stimulated luminescence (IRSL), thermoluminescence (TL) and radiocarbon methods. Four trenches were excavated cutting the fault scarp near the village of Bree in northeast Belgium. Altogether 17 luminescence samples and seven radiocarbon samples were investigated in order to set up a more reliable and precise chronological frame for the local coversand stratigraphy and the timing of Late Quaternary earthquake events. The chronological results indicate at least five accumulation periods for the coversand units in the area of interest. The oldest coversands were deposited during Saalian or Early Weichselian followed by coversands deposited during the Early and/or Middle Weichselian. At least three coversand units can be distinguished for the time span of the Late Weichselian to Holocene. Significant TL age underestimation of more than $20 \%$ compared to IRSL was found for samples from Trench 4. Most of the IRSL age estimates are in agreement with radiocarbon dates from the same section.
\end{abstract}

Keywords: Coversand, chronology, luminescence dating, earthquake, Roer Valley Graben, Pleistocene

\section{Introduction}

The Bree fault escarpment has been investigated to reconstruct the earthquake and rupturing history of the southwest border of the Roer Valley Graben known as the Feldbiss Fault Zone in northeast Belgium (Camelbeeck \& Meghraoui, 1996, 1998; Vanneste et al., 1999 and in press). Four trenches were excavated across the Bree fault scarp segment of the Feldbiss fault. These exposures provide evidence for multiple faulting events with clear surface displacement followed by colluviation. Possibly three surface fault displacements have occurred during the past 40,000 years, which are related to Late Quaternary earthquake events.

In this study, Infrared Optically Stimulated Luminescence (IRSL), Thermoluminescence (TL) and ra- diocarbon age estimates are presented in order to test the suitability of these dating techniques and to set up a more reliable chronological frame for the deposition history of the coversands in the study area and to agebracket the fault displacements. In the Netherlands, the coversands are divided into several units or members. According to Kasse (1997) the Older Coversand I corresponds to the Beverborg Member, Older Coversand II to the Lutterzand Member and Younger Coversand I and II to the Wierden Member of the Twente Formation, respectively. The Beverborg Member and the Lutterzand Member are separated by the Beuningen Gravel Bed.

Nine samples were taken from the NW wall of Trench 1bis in November 1999 and eight samples from the NW wall of Trench 4 in August 1998 resulting in 30 luminescence and seven radiocarbon age es- 
timates. The luminescence samples were taken from aeolian derived sediments, which were locally reworked by fluvial and colluvial activity prior to the final deposition, in the upper part of the section. A similar study has been carried out on Late Glacial coversand from a section near the village of Neer cutting the Peel Boundary Fault in the Netherlands (Frechen $\&$ van den Berg, this issue).

\section{Site Geology}

The sections near the village of Bree in northeast Belgium are located along the Bree fault scarp (Fig. 1). Trench 1 is situated close to the NW end of the Bree fault scarp, while trench 4 is closer to the south-east end, about $1 \mathrm{~km}$ and $4.5 \mathrm{~km}$ to the southeast of Bree, respectively (Fig. 2).

\section{Trench 1}

Trench 1 is located in the valley of a small creek crossing the fault scarp. The sediments exposed consist of silty coversands (Fig. 3). The upper part of the sequence has been reworked by the small local creek. The entire section was initially believed to be younger than the Beuningen gravel layer (22-17 ka BP, sensu Bateman \& van Huissteden, 1999) and hence of post- glacial and/or Holocene deposition age. Two gravel horizons, which are sharply displaced along a single fault plane, are intercalated in the coversands. The total offset of the different sediment units is about $1 \mathrm{~m}$, which is similar to the observed topographic offset (cp. Camelbeeck et al., 2000). A gleyed soil developed in the upper part of the coversands. The chronological and stratigraphical relation of this soil with the faulting event is complex. The gleyed horizon indicates that the main part of the soil predates the faulting event, while other parts of the soil may be younger (Vanneste et al., 2001). From geological and stratigraphic evidence only, it is difficult to date the single faulting event of Trench 1 accurately. Radiocarbon dating of supposedly inter-bedded organic material suggests an age of the faulting, and hence the timing of the earthquake event, between 1055 and 1335 years BP (AD 613 - 894) (Camelbeeck \& Meghraoui, 1996). Owing to the possible contamination of the dated organic material with modern roots, a new trench was excavated at site 1 (trench 1 bis) to date the deposition age of the coversand by the luminescence method, and so obtain independent age control.

In Trench 1, all luminescence samples were taken from locally reworked coversands designated to represent Late Glacial or possibly Holocene deposits

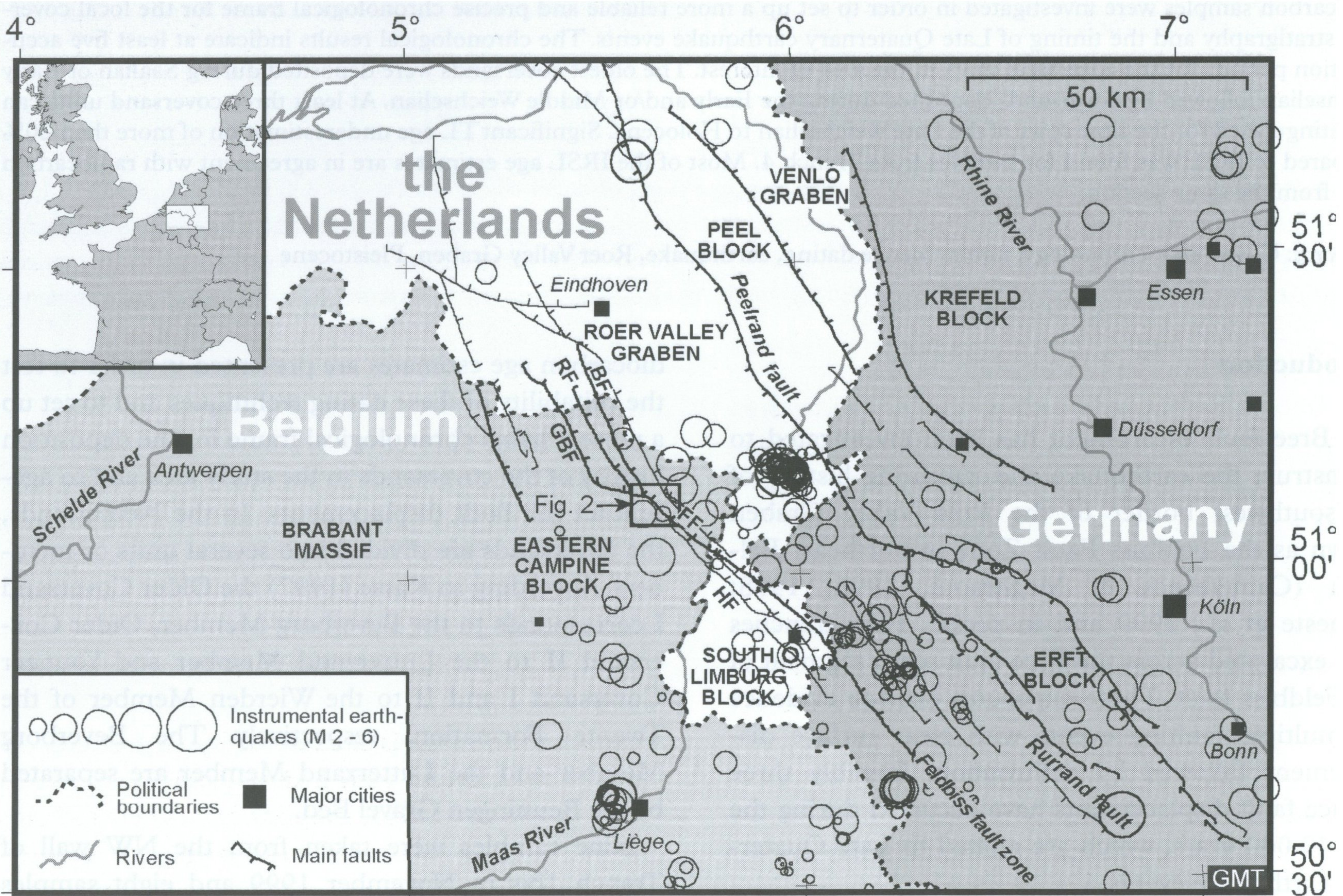

Fig. 1. Map showing the location of the Bree fault escarpment in Belgium and the location of instrumental earthquakes (adapted from Vanneste et al., 2001). 


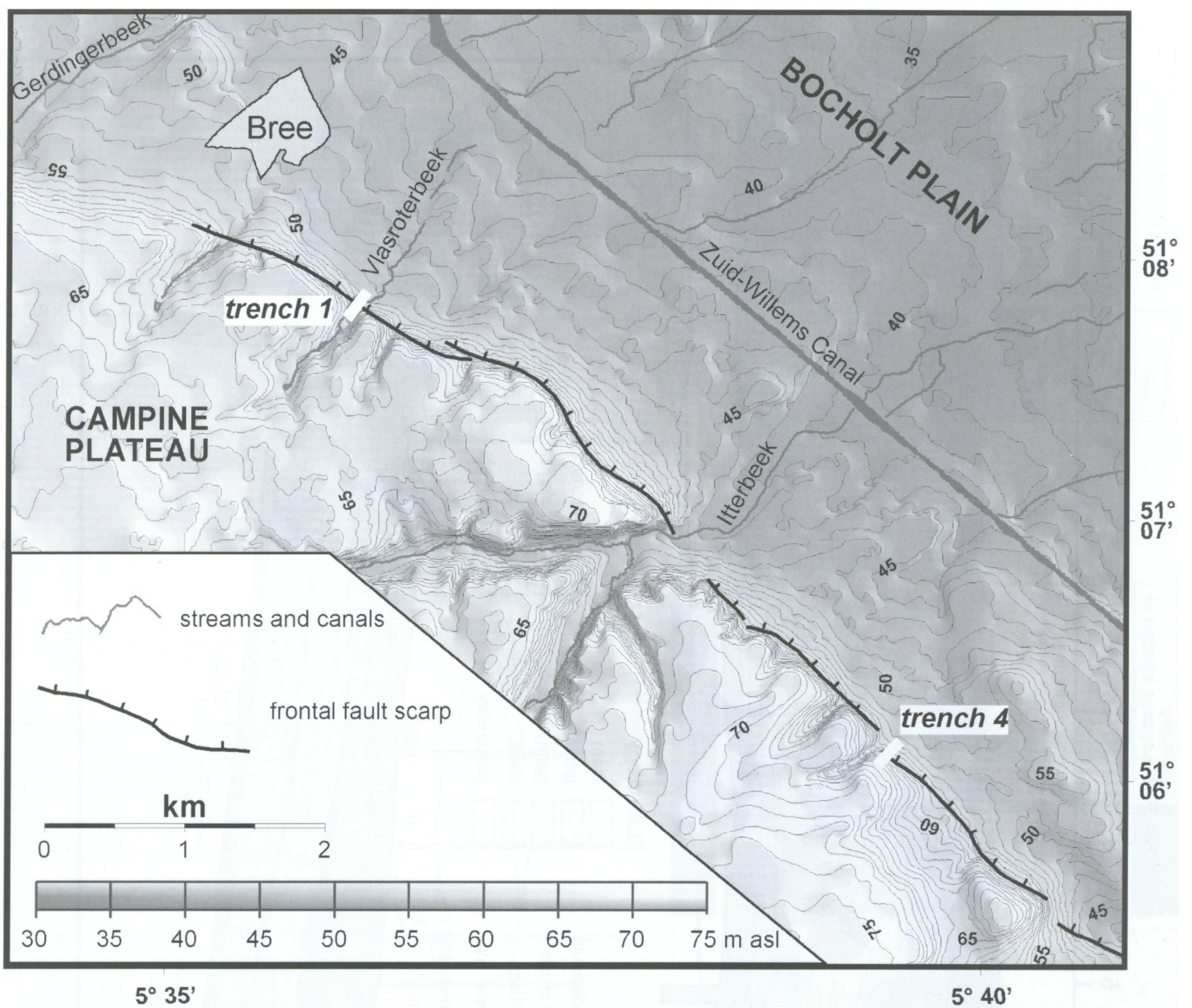

Fig. 2. Map showing the location of Trench 1 and 4 along the Bree fault escarpment in Belgium (adapted from Vanneste et al., 2001).

(Figs. 3 and 7). Five samples were taken from the foot-wall side and four samples from the hanging-wall side of the fault (NW wall), respectively.

The stratigraphically oldest sample (BR1) was taken from greenish fine- to medium-sized sand below a sandy loam intermingled by gravel. The reworked sandy loam is covered by a grey-green fluvio-aeolian loamy sand (sample BR2) topped by a first gravel layer. Sample BR3 was taken from similar fluvio-aeolian sediment between the first and the second intercalated gravel layer. The uppermost gravel layer truncates the lower one and seems to represent an important period of sediment remobilization similar to the Beuningen gravel bed in The Netherlands (e.g. Kolstrup, 1980). Sample BR4 was taken from grey-green fluvio-aeolian silty sand above the second gravel layer. The uppermost sample BR5 derives from fluvio-aeolian sediment about $30 \mathrm{~cm}$ below the modern soil. In the hanging-wall, samples BR6, BR8 and BR9 are from layers equivalent to those of samples $\mathrm{BR} 3, \mathrm{BR} 4$ and BR5, respectively, whereas sample BR7 was taken from a sand-rich lens within the uppermost gravel layer (Fig. 3).

\section{Trench 4}

The longest record of surface faulting in the study area of interest was exposed in Trench 4 (Vanneste et al., 2001). A well-defined single fault plane near the base of the overall escarpment displaces Middle Pleistocene gravel-rich sand belonging to the Main Terrace of the river Maas below the trench bottom (Fig. 4).

The hanging-wall is dominated by several units of reworked coversand with a characteristic succession of laminated coversand, irregular gravel bed and silty coversand at the upper part of the sequence. The upper units (gravel bed and overlying silty coversand) show a displacement of $0.12 \mathrm{~m}$ on the fault $(0.80 \mathrm{~m}$ including flexure, which is more in agreement with 


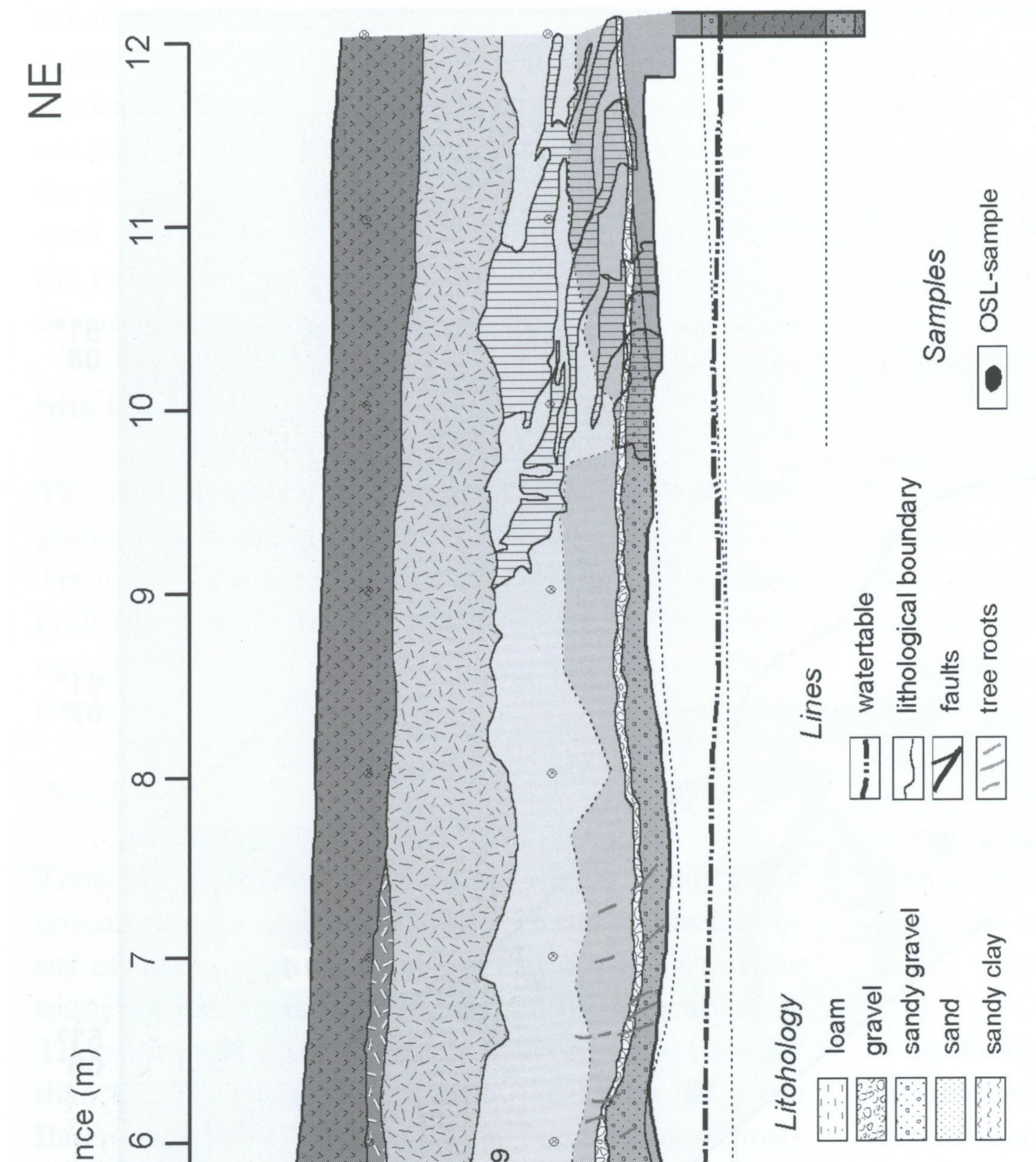

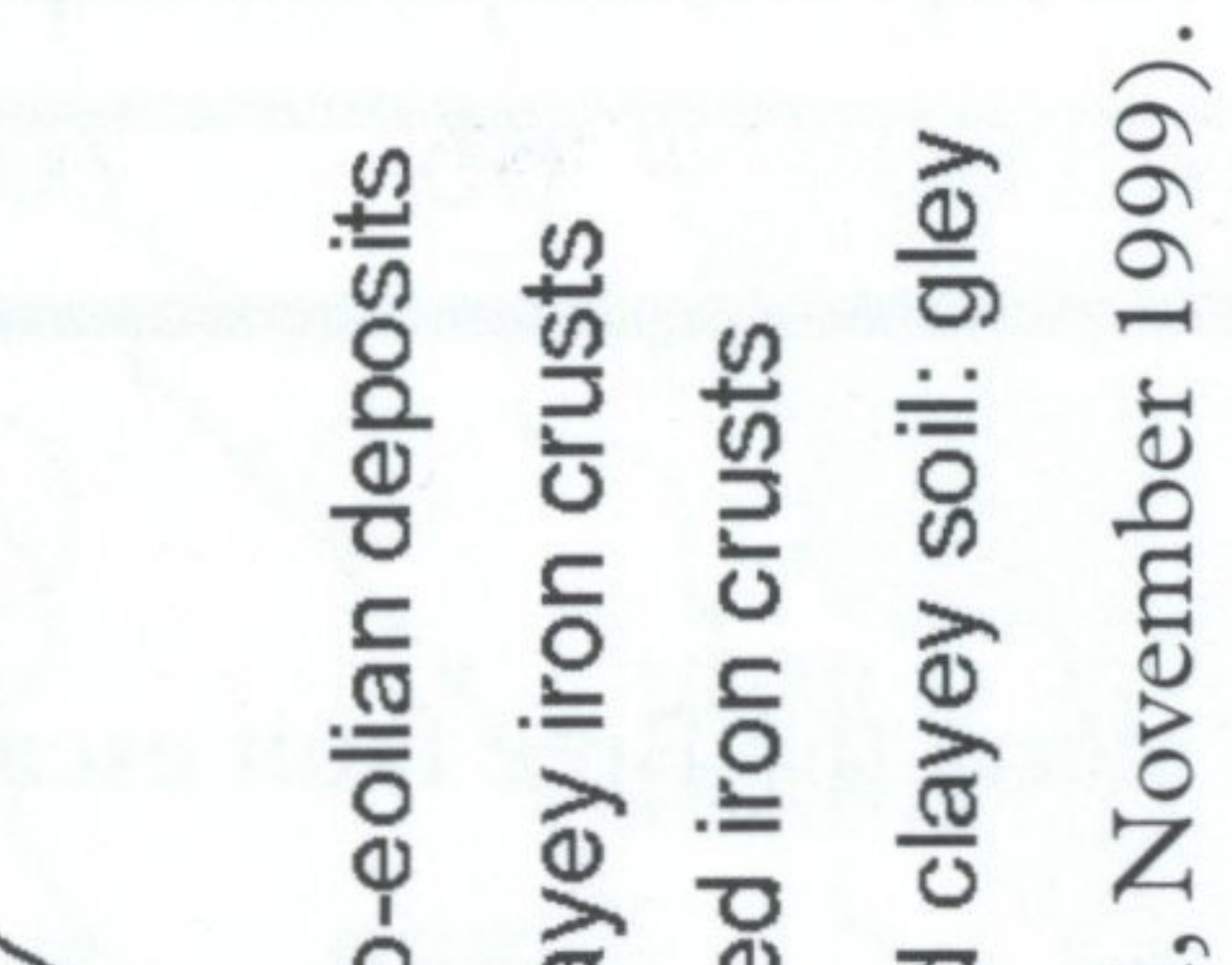

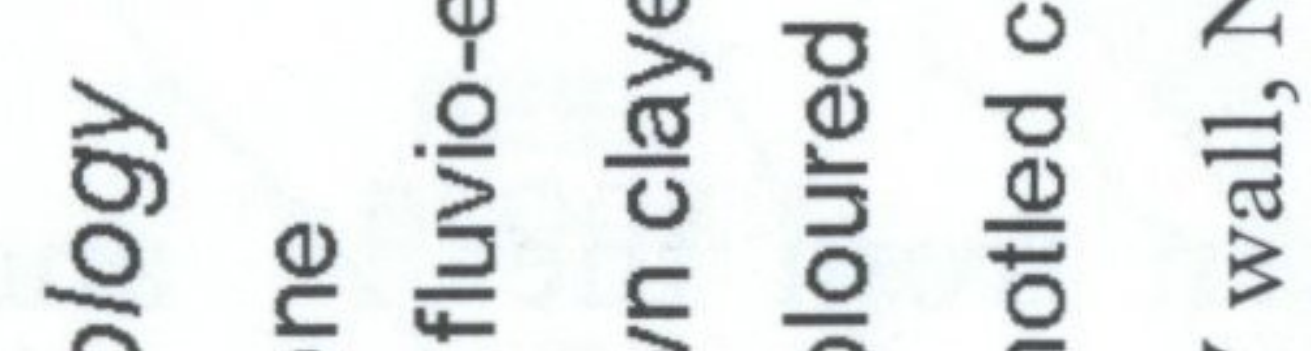

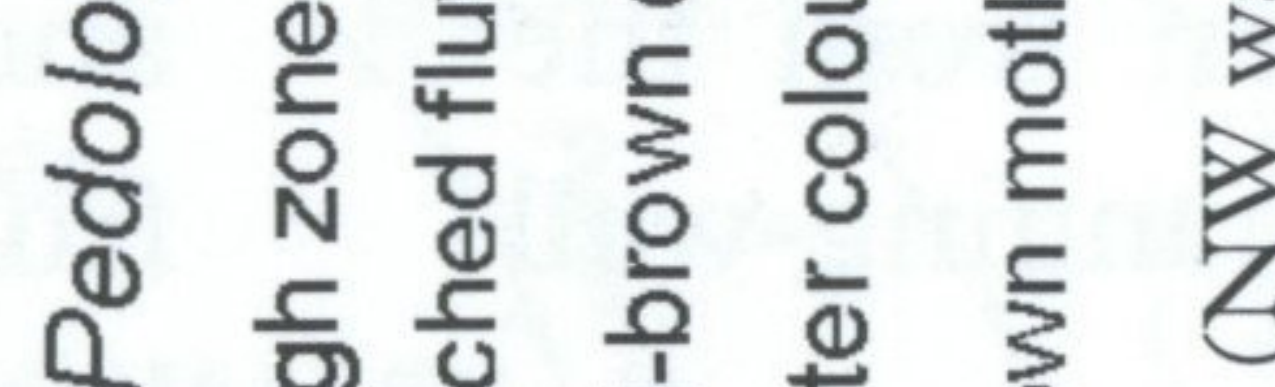

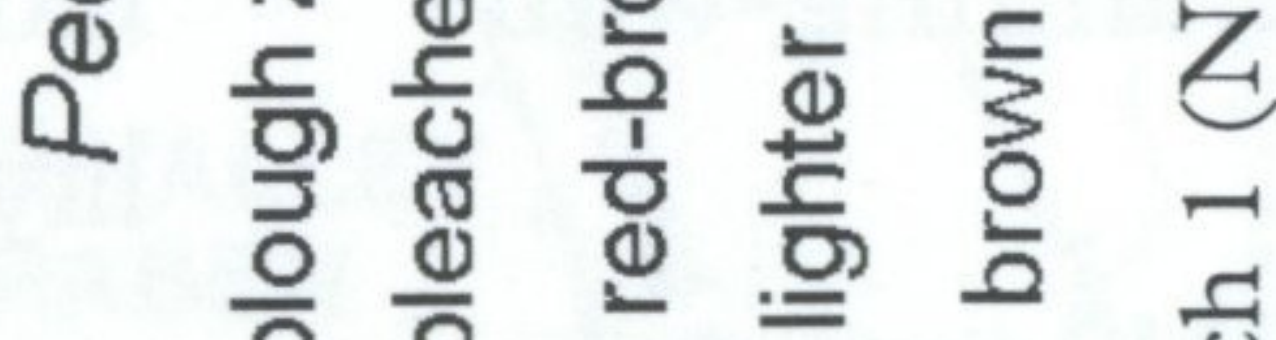

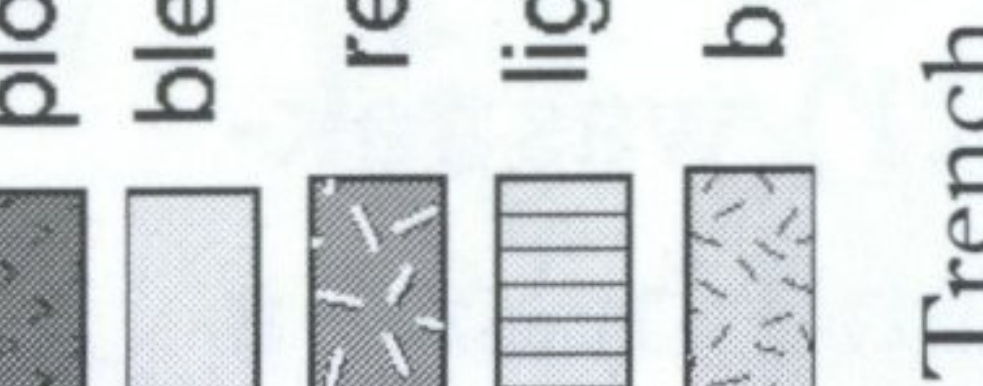

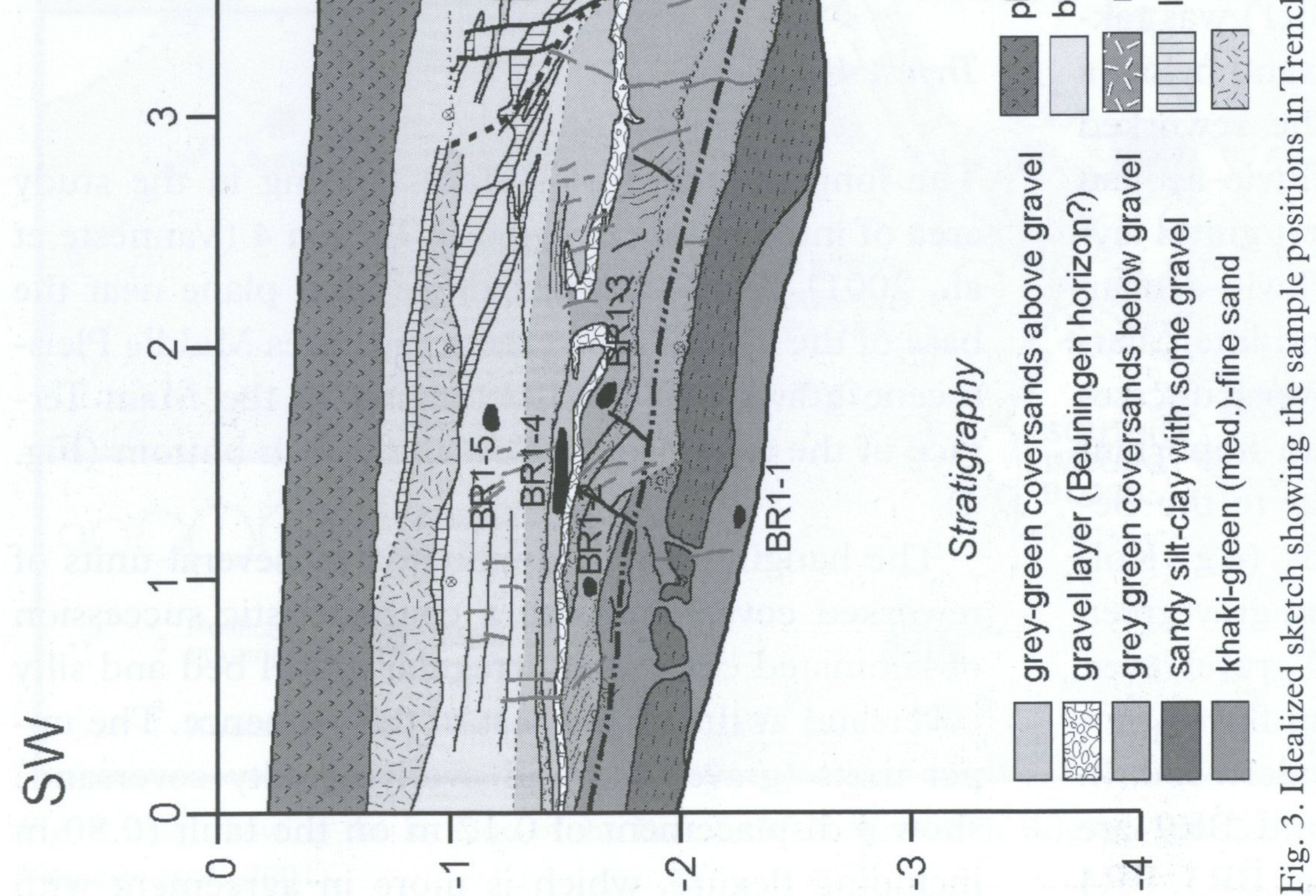



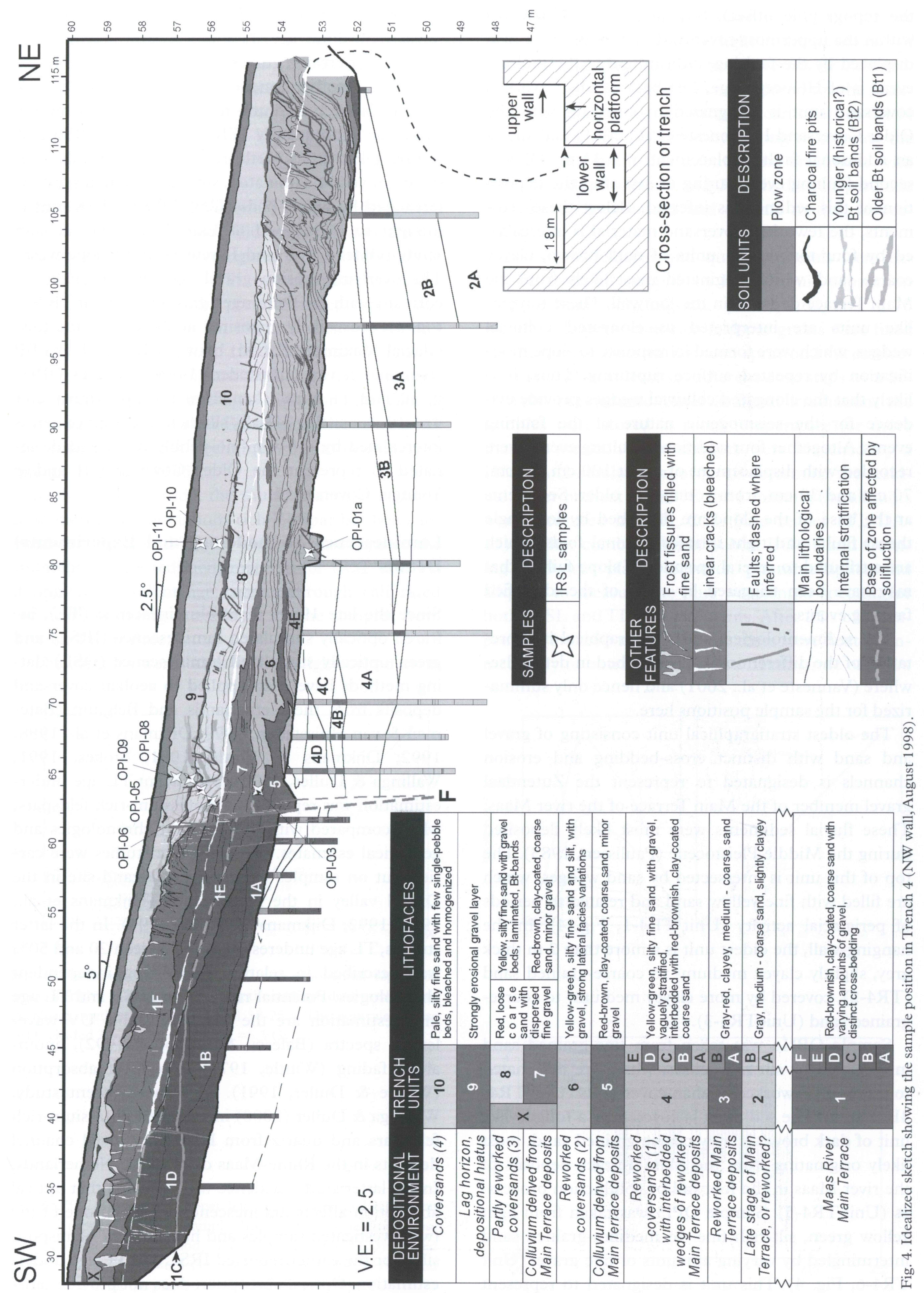
the topographic offset). Soil horizons ('Bt bands') within the uppermost coversand unit (Fig. 4) are also displaced by the faulting, indicating that the faulting event is of Holocene age. The base of this reworked coversand unit is designated to correlate with the Older Coversand I (Vanneste et al., 2001) and shows an additional fault displacement of $0.33 \mathrm{~m}$. Thus, a second faulting event during or just after the deposition of this sediment is inferred. Below these sediments, the reworked coversand material is intercalated by four tongue-like units of dark brown, clayey coarse sand, which originated most likely from the Main Terrace deposits in the footwall. These tonguelike units are interpreted as elongated colluvial wedges, which were formed in response to slope modification by repeated surface rupturing. Thus, it is likely that the elongated colluvial wedges provide evidence for the seismogenic nature of the faulting events. Altogether four additional faulting events were recorded with displacement of about $100 \mathrm{~cm}, 55 \mathrm{~cm}$, $70 \mathrm{~cm}$ and $30 \mathrm{~cm}$, from younger to older. Sediments at the base of the slope are disturbed by low-angle thrust faults and tight intraformational folds, which are attributed to several episodes of slope failure that may have been triggered by some of the identified faulting events.

The sedimentological and stratigraphical interpretation of the different units is described in detail elsewhere (Vanneste et al., 2001) and hence only summarized for the sample positions here.

The oldest stratigraphical unit consisting of gravel and sand with distinct cross-bedding and erosion channels is designated to represent the Zutendaal gravel member of the Main Terrace of the river Maas. These fluvial sediments were most likely deposited during the Middle Pleistocene (Paulissen, 1983). The top of this unit is intersected by sand wedges, which are filled with fine yellow sand and related to periods of periglacial activity (Unit TR4-1, Fig. 4). In the hanging-wall, the oldest unit is a more than $2 \mathrm{~m}$ thick grey, slightly clayey medium- to coarse-grained sand (TR4-2), covered by more clayey medium- to coarsegrained sand (Unit TR4-3).

Sample OPI1 a was taken from fine-grained sand intercalated by silt-rich lenses, which are designated to represent reworked Saalian coversands (Unit TR4$4 \mathrm{E}$, Fig. 4). The sediment is covered by a tongue-like unit of dark brown, clayey coarse-grained sand, most likely originating from the Main Terrace deposits of the river Maas in the footwall by solifluction processes (Unit TR4-5). Sample OPI3 was taken from light yellow green, silt-rich fine- to medium-grained sand intermingled by varying amounts of fine gravel (Unit TR4-6, Fig. 4). This unit is designated to represent reworked coversands of Early and/or Middle Weichselian deposition age. It shows a stratification with some minor erosion gullies and extensive lateral facies variation. Another tongue-like unit filled with dark brown, clay-rich medium- to coarse-grained sand was deposited subsequently (TR4-7). Samples OPI5 and 6 were taken from partly reworked coversands consisting of yellow, laminated, silty fine-grained sand intercalated by gravel beds (Unit TR4-8). This unit is thought to correspond to Late Weichselian aeolian sands (Older Coversand I) reworked by slope wash. The overlying erosion gravel layer is designated to correlate with the Beuningen gravel bed (Unit TR4-9, Fig. 4), most likely deposited at the end of the Last Glacial Maximum (LGM) between 22 and $17 \mathrm{ka} \mathrm{BP}$ (Bateman \& van Huissteden, 1999). Samples OPI8, 9,10 and 11 were taken from the uppermost unit $\operatorname{Tr} 4-10$, consisting of pale, silt-rich fine-grained sands intercalated by a few mono-pebble beds, and designated to represent the Older Coversand II and/or Younger Coversand I.

\section{Luminescence Methodology and Experimental Details}

Since the late 1980s thermoluminescence (TL), infrared optically stimulated luminescence (IRSL) and green optically stimulated luminescence (OSL) dating methods have been applied to aeolian coversand deposits from the Netherlands and Belgium (Bateman \& van Huissteden, 1999; Dijkmans et al., 1988, 1992; Dijkmans \& Wintle, 1991; Stokes, 1991; Wallinga \& Duller, 2000). Significant TL age underestimation was reported for potassium-rich feldspars, when compared with independent chronologies and geological estimates. Most of these studies were carried out on samples from the Lutterzand site in the Dinkel valley in the Netherlands (Dijkmans et al., 1988, 1992; Dijkmans \& Wintle, 1991). In the latter studies, TL age underestimation between 20 and $50 \%$ was described in relation to existing independent chronologies. Potential reasons for IRSL and TL age underestimation are the use of unstable UV wavelength spectra (Balescu \& Lamothe, 1992), anomalous fading (Wintle, 1973) or optical absorption (Wintle \& Duller, 1991). In a more recent study, Wallinga \& Duller (2000) investigated potassium-rich feldspars and quartz from Holocene fluvial channel deposits in the Rhine-Maas delta in the Netherlands. In the latter study, evidence was provided that optical absorption affects luminescence signals in one of the two investigated samples and hence might be responsible for the earlier reported IRSL and TL age underestimation. Optical absorption does not provide satis- 
factory evidence for the total amount of IRSL and TL age underestimation and needs further investigation. Therefore, Wallinga \& Duller (2000) suggest unknown reasons for the luminescence age underestimation besides the optical absorption. However, the latter statement is only valid if the present independent age chronology is correct for the record under investigation.

In order to avoid IRSL and TL age underestimation on potassium-rich feldspars, monomineralic quartz samples were investigated from coversands in the Netherlands. These OSL age estimates yielded a better agreement with present independent age chronologies (Smith et al., 1991; Stokes, 1991; Bateman \& van Huissteden, 1999; Wallinga \& Duller, 2000). However, significant OSL age overestimation was determined in a previous study for Late Glacial fluvial sand from the river Emscher in Germany using the multiple aliquot technique on monomineralic quartz (Frechen, 1995).

In the present study, the multiple aliquot additive dose method on potassium-rich feldspar has been applied for IRSL and TL in order to test further the suitability of the sediment material for IRSL and TL dating. Independent age control through calibrated radiocarbon dating is available for the samples from Trench 4 near Bree.

The samples were taken in light-tight cylinders in
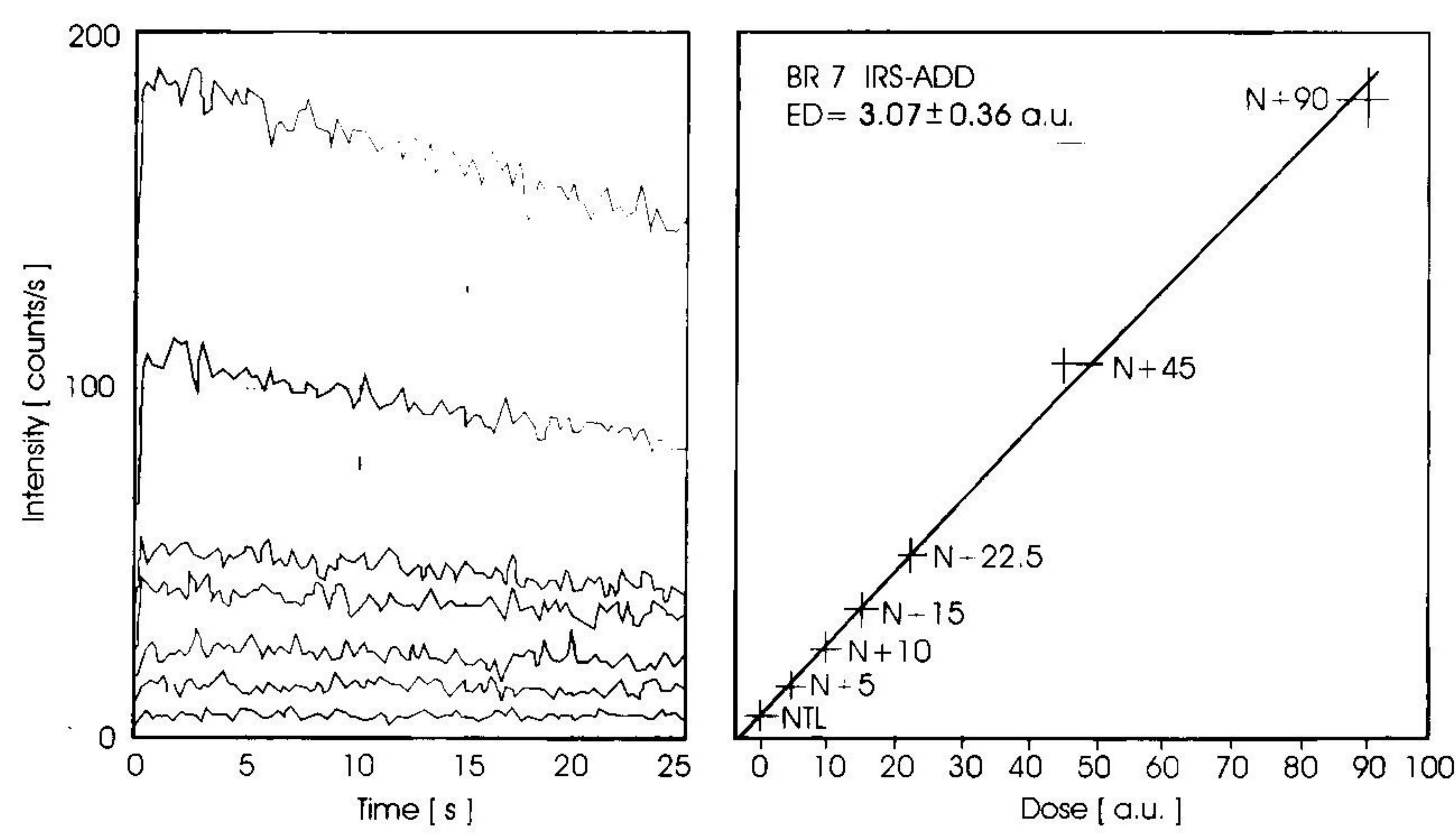

Fig. 5a. Infrared decay curves (left) and exponential regression analysis (right) of sample BR7 using the additive dose method (total bleach method) for the integral 10-25 s. The equivalent dose (ED) yielded $3.07 \pm 0.36$ a.u. ( 1 a.u. $=6.3 \mathrm{~Gy}$ ). the field. The outer light-exposed part of the sample was removed under subdued light in the laboratory of the Geological Institute at the University of Cologne, Germany. The sediments were prepared for the luminescence analysis by removing the carbonate in $0.1 \mathrm{~N}$ hydrochloric acid, followed by sieving to separate the $100-200 \mu \mathrm{m}$ grain-size fraction and treatment with $0.01 \mathrm{~N}$ sodium oxalate and $30 \%$ hydrogen peroxide to remove clay coatings and organic matter, respectively.

Potassium feldspar and quartz minerals were extracted from all samples by heavy liquid separation with sodium polytungstate $(2.58,2.62$ and 2.70 $\left.\mathrm{g} / \mathrm{cm}^{3}\right)$. The potassium-rich feldspar grains were fixed on aluminium discs with silicon spray and successively irradiated in at least six different dose steps by a Sr$90 /$ Y-90 beta source. After artificial irradiation, the samples were stored at room temperature for more than six weeks. A few aliquots were bleached by a Hönle sol2 sun lamp in order to determine the residual. After preheat at $230^{\circ} \mathrm{C}$ for 1 minute, the aliquots were measured in a TL/OSL Risø reader (TL-DA15). A filter combination of Schott BG-39 and Corning 7-59 was placed between photomultiplier and aliquots to measure the blue wavelength spectra, for both IRSL and TL measurements. After $25 \mathrm{~s}$ of IR exposure $(880 \pm 80 \mathrm{~nm})$, the same discs were heated immediately to obtain their TL at a heating rate of $5^{\circ} \mathrm{C} / \mathrm{s}$
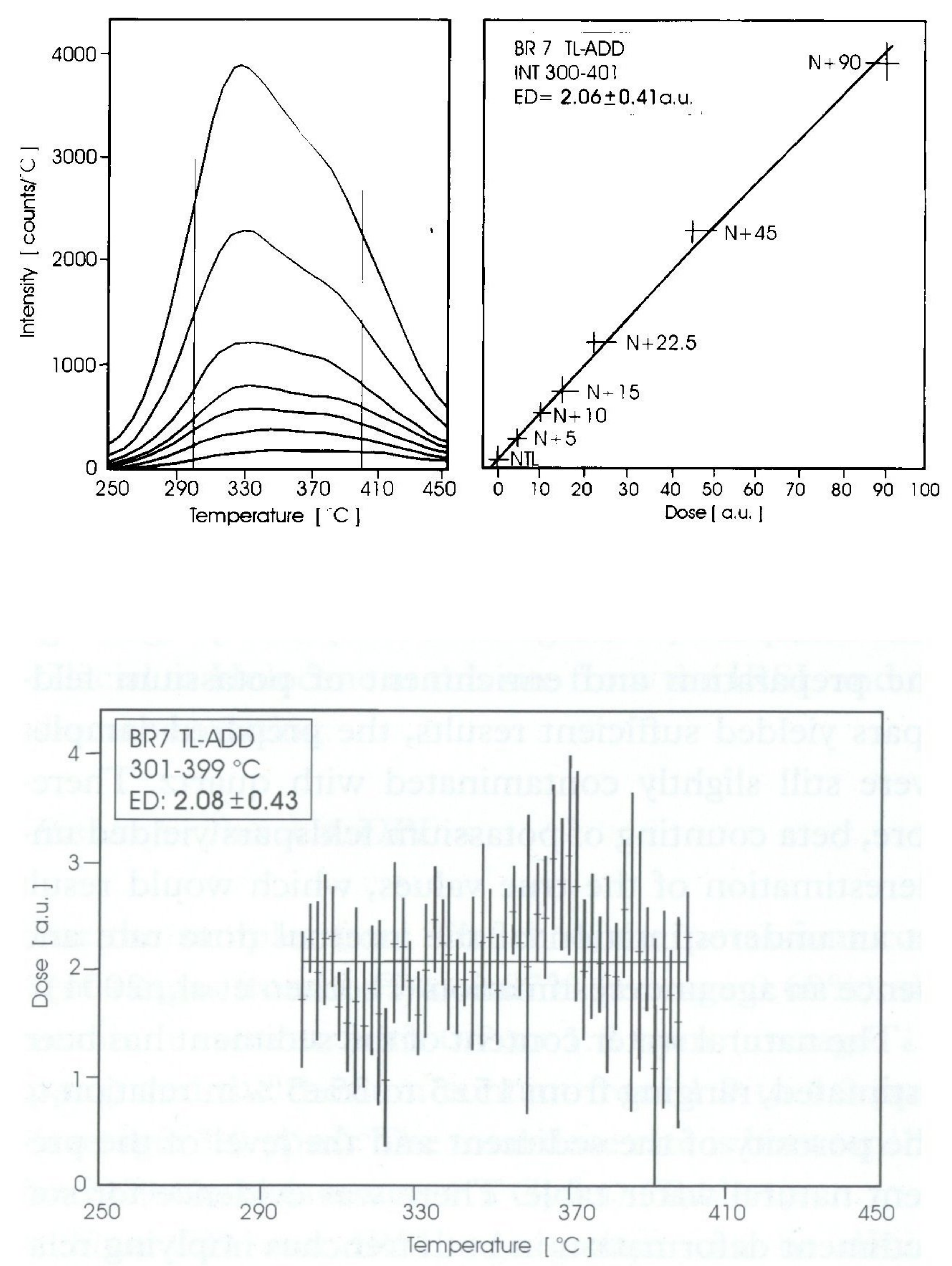

Fig. 5b. TL glow curves (upper left) and exponential regression analysis (upper right) of sample BR7 using the additive dose method (total bleach method). The equivalent dose (ED) yielded $2.06 \pm 0.41$ a.u. $(1 \mathrm{a} . u .=6.3 \mathrm{~Gy})$ for the integral $\left(300-401^{\circ} \mathrm{C}\right)$ and $2.08 \pm 0.43$ a.u. for the plateau (lower) between $301-399^{\circ} \mathrm{C}$. 


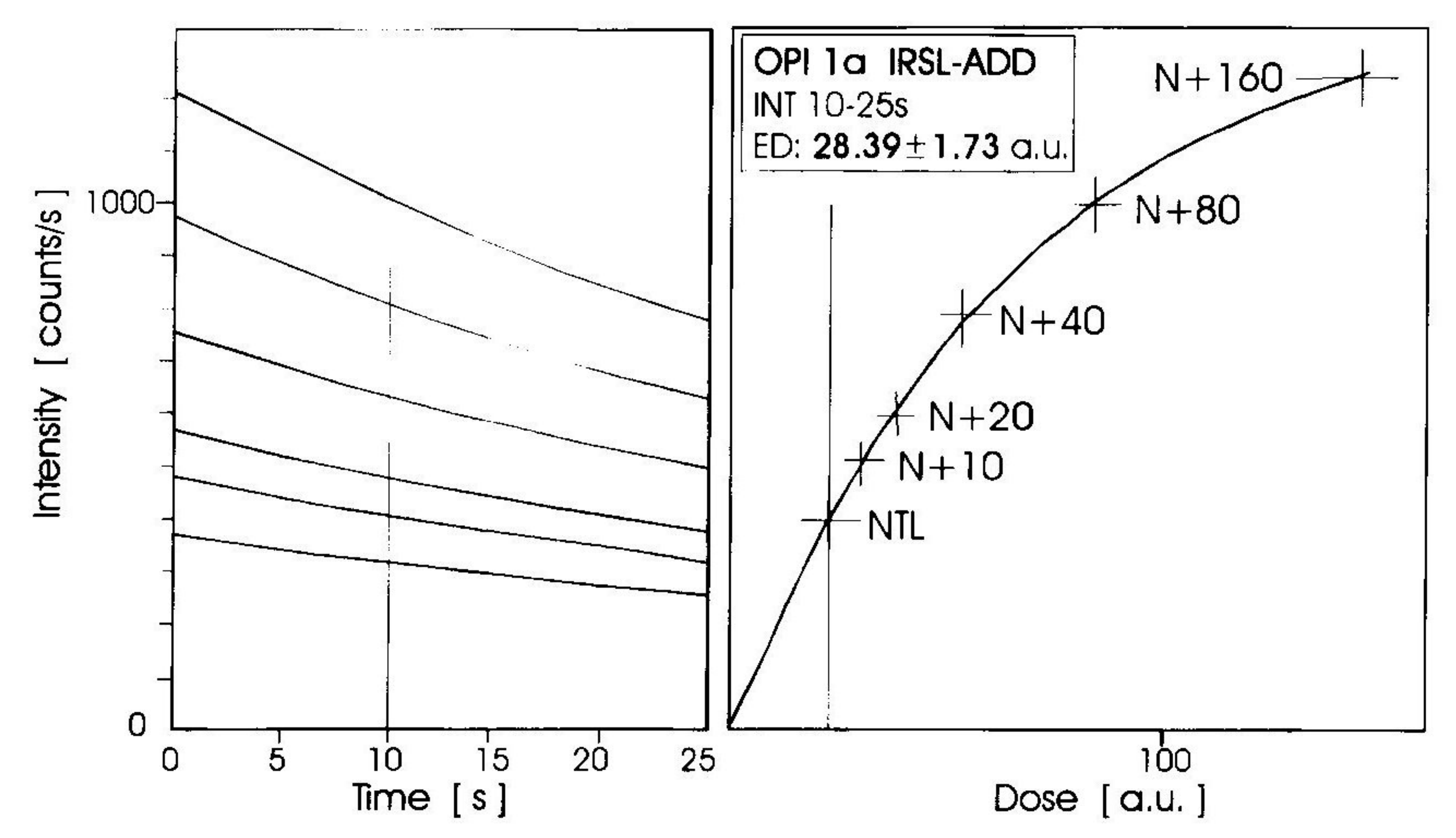

Fig. 6a. Infrared decay curves (left) and exponential regression analysis (right) of sample BR1 a using the additive dose method (total bleach method) for the integral 10-25 s. The equivalent dose (ED) yielded $28.39 \pm 1.73$ ( 1 a.u. $=6.3 \mathrm{~Gy}$ ).

Fig. 6b. TL glow curves (upper left) and exponential regression analysis (upper right) of sample BR1a using the additive dose method (total bleach method). The equivalent dose (ED) yielded $27.33 \pm 2.24$ a.u. $(1$ a.u. $=6.3 \mathrm{~Gy})$ for the integral $\left(300-401^{\circ} \mathrm{C}\right)$ between 301 and $400^{\circ} \mathrm{C}$. The plateau ED was not determined owing to an increasing ED with temperature (lower).

up to $450^{\circ} \mathrm{C}$. Second glow normalization was applied in order to reduce the disc-to-disc scatter. Dose-dependent sensitivity changes were not observed. Owing to the poor signal/background ratio, it was necessary to apply the background subtraction for IRSL.

Equivalent dose values were obtained by integrating the 10 to $25 \mathrm{~s}$ region of the IR decay curve and the $300-401^{\circ} \mathrm{C}$ region of the TL glow curve (Fig. 5ab, 6a-b).

An exponential growth curve was fitted for the different dose steps and compared with the natural luminescence signal to estimate the equivalent dose using the software developed by Rainer Grün, Canberra.

Dose rates for all samples were obtained from potassium, uranium and thorium content, as measured by gamma spectrometry in the laboratory, assuming a radioactive equilibrium for the decay chains and a potassium content of $9 \pm 1 \%$ for the potassiumrich feldspars (Wallinga \& Duller, 2000). Although the preparation and enrichment of potassium feldspars yielded sufficient results, the prepared samples were still slightly contaminated with quartz. Therefore, beta counting of potassium feldspars yielded underestimation of the true values, which would result in an underestimation of the internal dose rate and hence an age underestimation (Frechen et al., 2001).

The natural water content of the sediment has been estimated, ranging from $15 \pm 5$ to $35 \pm 5 \%$ in relation to the porosity of the sediment and the level of the present natural water table. There was evidence for soft sediment deformation in both trenches implying rela-
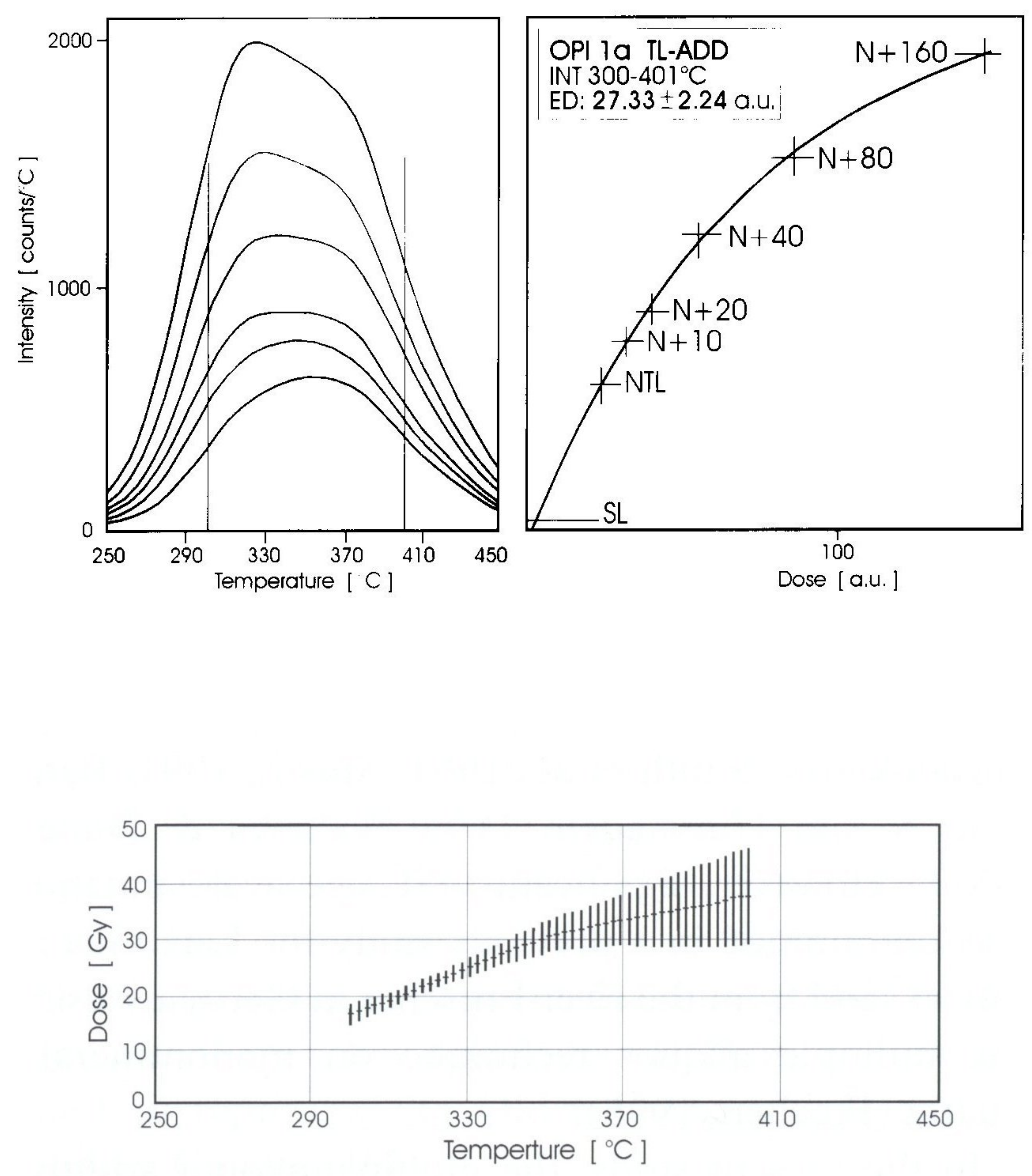

tively high water content for the periods when those features were formed.

Fading experiments have not indicated anomalous fading after a delay of 4 weeks and 12 months after artificial irradiation.

\section{Results for Trench 1:BR}

For the samples from Trench 1, the potassium content ranges from 0.44 to $0.87 \%$ (average $0.58 \%$ ), the uranium content from 0.5 to $1.2 \mathrm{ppm}$ (average: 0.8 $\mathrm{ppm}$ ) and the thorium content from 1.3 to $3.4 \mathrm{ppm}$ (average: $2.0 \mathrm{ppm}$ ). The total dose rate is between 1.0 and $1.6 \mathrm{~Gy} / \mathrm{ka}$ (average: $1.2 \mathrm{~Gy} / \mathrm{ka}$ ) (table 1).

There are two clusters for the IRSL and TL equivalent dose (ED) values (table 2). The oldest sample BR1 has the highest ED, $65.6 \pm 4.8 \mathrm{~Gy}$ and $496 \pm 71$ Gy for IRSL and TL, respectively. It is likely that the latter sample was not well bleached prior to deposition owing to significant TL equivalent dose overestimation, which is about eight times higher than those of the other samples.

The remaining eight samples (BR2-9) belong to a cluster. The ED values range from $18.1 \pm 1.4$ to $23.8 \pm 1.8$ and from $13.0 \pm 3.8$ to $18.9 \pm 2.1 \mathrm{~Gy}$ for IRSL and TL, respectively. There is no systematic ED increase with depth. The TL values are systematically smaller than the IRSL values indicating a TL equivalent dose underestimation of about $21 \%$ compared to those of IRSL.

Two IRSL age clusters were determined for the sediments of Trench 1 (table 2). 
Table 1. Dosimetric results of the samples from Trench 1 (BR) and Trench 4 (OPI). Alpha efficiency was estimated to $0.08 \pm 0.01$ and the internal potassium content to $9 \pm 1 \%$. [Gy/ka means Gray per thousand years] The cosmic dose attenuation is negligible for the present data set and so was not calculated.

Bree Trench 1

\begin{tabular}{|c|c|c|c|c|c|}
\hline Sample & $\begin{array}{l}\text { Uranium } \\
{[\mathrm{ppm}]}\end{array}$ & $\begin{array}{l}\text { Thorium } \\
\text { [ppm] }\end{array}$ & $\begin{array}{l}\text { Potassium } \\
{[\%]}\end{array}$ & $\begin{array}{l}\text { Moisture } \\
{[\%]}\end{array}$ & $\begin{array}{l}\text { Dose rate } \\
{[\mathrm{Gy} / \mathrm{ka}]}\end{array}$ \\
\hline BR1 & $0.95 \pm 0.07$ & $1.69 \pm 0.12$ & $0.70 \pm 0.05$ & $35 \pm 5$ & $1.20 \pm 0.13$ \\
\hline BR2 & $0.70 \pm 0.05$ & $1.76 \pm 0.12$ & $0.49 \pm 0.03$ & $35 \pm 5$ & $1.04 \pm 0.13$ \\
\hline BR3 & $0.64 \pm 0.04$ & $1.46 \pm 0.10$ & $0.44 \pm 0.03$ & $35 \pm 5$ & $0.98 \pm 0.13$ \\
\hline BR4 & $0.82 \pm 0.06$ & $2.20 \pm 0.15$ & $0.63 \pm 0.03$ & $30 \pm 5$ & $1.22 \pm 0.13$ \\
\hline BR5 & $0.69 \pm 0.05$ & $2.05 \pm 0.14$ & $0.53 \pm 0.03$ & $25 \pm 5$ & $1.17 \pm 0.13$ \\
\hline BR6 & $0.53 \pm 0.04$ & $1.29 \pm 0.09$ & $0.50 \pm 0.03$ & $35 \pm 5$ & $0.99 \pm 0.13$ \\
\hline BR7 & $0.63 \pm 0.04$ & $1.67 \pm 0.12$ & $0.48 \pm 0.03$ & $35 \pm 5$ & $1.02 \pm 0.13$ \\
\hline BR8 & $1.21 \pm 0.08$ & $3.42 \pm 0.24$ & $0.87 \pm 0.06$ & $30 \pm 5$ & $1.59 \pm 0.15$ \\
\hline BR9 & $0.81 \pm 0.06$ & $2.18 \pm 0.15$ & $0.58 \pm 0.04$ & $25 \pm 5$ & $1.24 \pm 0.13$ \\
\hline
\end{tabular}

Bree Trench 4

\begin{tabular}{llllll} 
OPI1A & $1.04 \pm 0.07$ & $3.17 \pm 0.22$ & $0.67 \pm 0.03$ & $25 \pm 5$ & $1.41 \pm 0.13$ \\
OPI3 & $0.70 \pm 0.05$ & $2.45 \pm 0.17$ & $0.45 \pm 0.02$ & $25 \pm 5$ & $1.14 \pm 0.13$ \\
OPI5 & $1.16 \pm 0.08$ & $3.04 \pm 0.21$ & $0.79 \pm 0.04$ & $20 \pm 5$ & $1.59 \pm 0.14$ \\
OPI6 & $0.90 \pm 0.06$ & $3.53 \pm 0.25$ & $0.73 \pm 0.04$ & $20 \pm 5$ & $1.52 \pm 0.14$ \\
OPI8 & $1.19 \pm 0.08$ & $3.47 \pm 0.24$ & $0.76 \pm 0.04$ & $15 \pm 5$ & $1.68 \pm 0.14$ \\
OPI9 & $1.46 \pm 0.10$ & $4.31 \pm 0.30$ & $0.87 \pm 0.04$ & $15 \pm 5$ & $1.89 \pm 0.14$ \\
OPI10 & $0.69 \pm 0.05$ & $1.88 \pm 0.13$ & $0.52 \pm 0.03$ & $15 \pm 5$ & $1.25 \pm 0.13$ \\
OPI11 & $0.88 \pm 0.06$ & $2.52 \pm 0.18$ & $0.64 \pm 0.03$ & $15 \pm 5$ & $1.44 \pm 0.13$ \\
\hline
\end{tabular}

Internal potassium content: $\quad 9 \pm 1 \%$ (following Wallinga \& Duller 2000)

Alpha efficiency: $\quad 0.08 \pm 0.01$

Cosmic dose rate: $\quad 150 \mu \mathrm{Gy} / \mathrm{a}$

Moisture: $\quad$ estimated

The lowermost sample BR1 has an IRSL age estimate of $44.6 \pm 6.2 \mathrm{ka}$. The other eight samples, BR2-9, yielded IRSL age estimates ranging from $18.0 \pm 2.7$ to $12.9 \pm 2.4 \mathrm{ka}$. The mean value of the latter data cluster is $15.1 \pm 1.5 \mathrm{ka}$ (Fig. 7).

Sample BR5 was taken near to an iron-enriched soil, which was not taken into account for the dosimetry. Thus, the IRSL age estimate of sample BR5 could be slightly overestimated owing to a dose rate underestimation. The sample-to-sample scattering and the relatively large standard deviation of 10 to $30 \%$ do not allow a more precise chronological resolution. However, the average age value of the three samples (BR2, 3 and 6) below the uppermost gravel layer yielded $16.8 \pm 1.8 \mathrm{ka}$. The TL results for samples BR2 and BR3 were multiplied by a factor of 1.21 , owing to the average TL equivalent dose and age underestimation for this part of the data set. The average IRSL age estimate is in agreement with the geologically expected age estimates. The sand lens within the gravel layer yielded an IRSL age of $15.4 \pm 2.8 \mathrm{ka}$ (sample BR7) and the four data points above this gravel layer
15.4 $\pm 2.3 \mathrm{ka}$ (samples BR4, 5, 8, 9). From a stratigraphical point of view, it is likely that the uppermost gravel layer correlates with the Beuningen gravel bed. The luminescence dating results clearly indicate serious problems with the reliability of earlier radiocarbon dating, which yielded age estimates less than $2 \mathrm{ka}$ for charcoal from most of the sands exposed in Trench 1 (Camelbeeck \& Meghraoui, 1996, 1998). This also implies that the timing of the most recent faulting cannot be constrained better than Late Glacial to Holocene at this site from the IRSL and radiocarbon dating.

\section{Results for Trench 4: OPI}

For the samples from Trench 4, the potassium content ranges from 0.45 to $0.87 \%$ (average $0.68 \%$ ), the uranium content from 0.7 to $1.5 \mathrm{ppm}$ (average: 1.0 $\mathrm{ppm}$ ) and the thorium content from 1.9 to $4.3 \mathrm{ppm}$ (average: $3.0 \mathrm{ppm}$ ). The total dose rate is between 1.1 and $1.9 \mathrm{~Gy} / \mathrm{ka}$ (average: $1.5 \mathrm{~Gy} / \mathrm{ka}$ ) (Table 1 ).

Four ED and IRSL age groups can be distin- 
Table 2. Results of equivalent dose determination, TL and IRSL age estimates for Trench 1 and 4 at the section at Bree.

Bree Trench 1

\begin{tabular}{|c|c|c|c|c|}
\hline \multirow[t]{2}{*}{ Sample } & TLADD & IRSL ADD & TL ADD & IRSL ADD \\
\hline & \multicolumn{2}{|c|}{ Palaeodose in Gray [Gy] } & \multicolumn{2}{|c|}{ Age in 1000 years [ka] } \\
\hline BR1 & $496.4 \pm 70.6$ & $65.6 \pm 4.8$ & $336 \pm 62$ & $44.6 \pm 6.2$ \\
\hline BR2 & $18.8 \pm 3.1$ & No solution & $14.7 \pm 3.1$ & No solution \\
\hline BR3 & $17.9 \pm 5.4$ & No solution & $14.8 \pm 4.9$ & No solution \\
\hline BR4 & $18.1 \pm 2.3$ & $23.2 \pm 1.5$ & $12.6 \pm 2.2$ & $16.3 \pm 2.2$ \\
\hline BR5 & $18.9 \pm 2.1$ & $23.8 \pm 1.8$ & $14.3 \pm 2.4$ & $18.0 \pm 2.7$ \\
\hline BR6 & $15.4 \pm 1.9$ & $18.1 \pm 1.4$ & $12.6 \pm 2.3$ & $14.8 \pm 2.4$ \\
\hline BR7 & $13.0 \pm 3.8$ & $19.3 \pm 2.3$ & $10.4 \pm 3.3$ & $15.4 \pm 2.8$ \\
\hline BR8 & No solution & $22.6 \pm 3.5$ & No solution & $12.9 \pm 2.4$ \\
\hline BR9 & $16.9 \pm 3.6$ & $19.7 \pm 1.3$ & $12.1 \pm 3.0$ & $14.2 \pm 2.0$ \\
\hline
\end{tabular}

Bree Trench 4

Sample

TLADD

IRSL ADD

TLADD

IRSL ADD

Palaeodose in Gray [Gy]

Age in 1000 years $[\mathrm{ka}]$

\begin{tabular}{lcrrr} 
OPI1 a & $175.2 \pm 29.7$ & $143.0 \pm 2.0$ & $124.2 \pm 24.0$ & $101.4 \pm 9.6$ \\
OPI3 & $68.0 \pm 9.5$ & $78.8 \pm 5.3$ & $59.6 \pm 10.6$ & $69.0 \pm 9.0$ \\
OPI5 & $17.4 \pm 1.9$ & $19.0 \pm 2.0$ & $10.9 \pm 1.5$ & $12.0 \pm 1.6$ \\
OPI6 & $27.6 \pm 2.3$ & $33.8 \pm 2.3$ & $18.2 \pm 2.2$ & $22.2 \pm 2.5$ \\
OPI8 & $18.4 \pm 1.5$ & $19.1 \pm 2.5$ & $11.0 \pm 1.3$ & $11.4 \pm 1.8$ \\
OPI9 & $14.3 \pm 1.8$ & $12.9 \pm 2.0$ & $7.6 \pm 1.1$ & $6.8 \pm 1.2$ \\
OPI10 & $12.7 \pm 0.7$ & $12.4 \pm 0.6$ & $10.1 \pm 1.2$ & $9.9 \pm 1.1$ \\
OPI11 & No solution & $13.8 \pm 2.4$ & No solution & $9.6 \pm 1.9$ \\
\hline
\end{tabular}

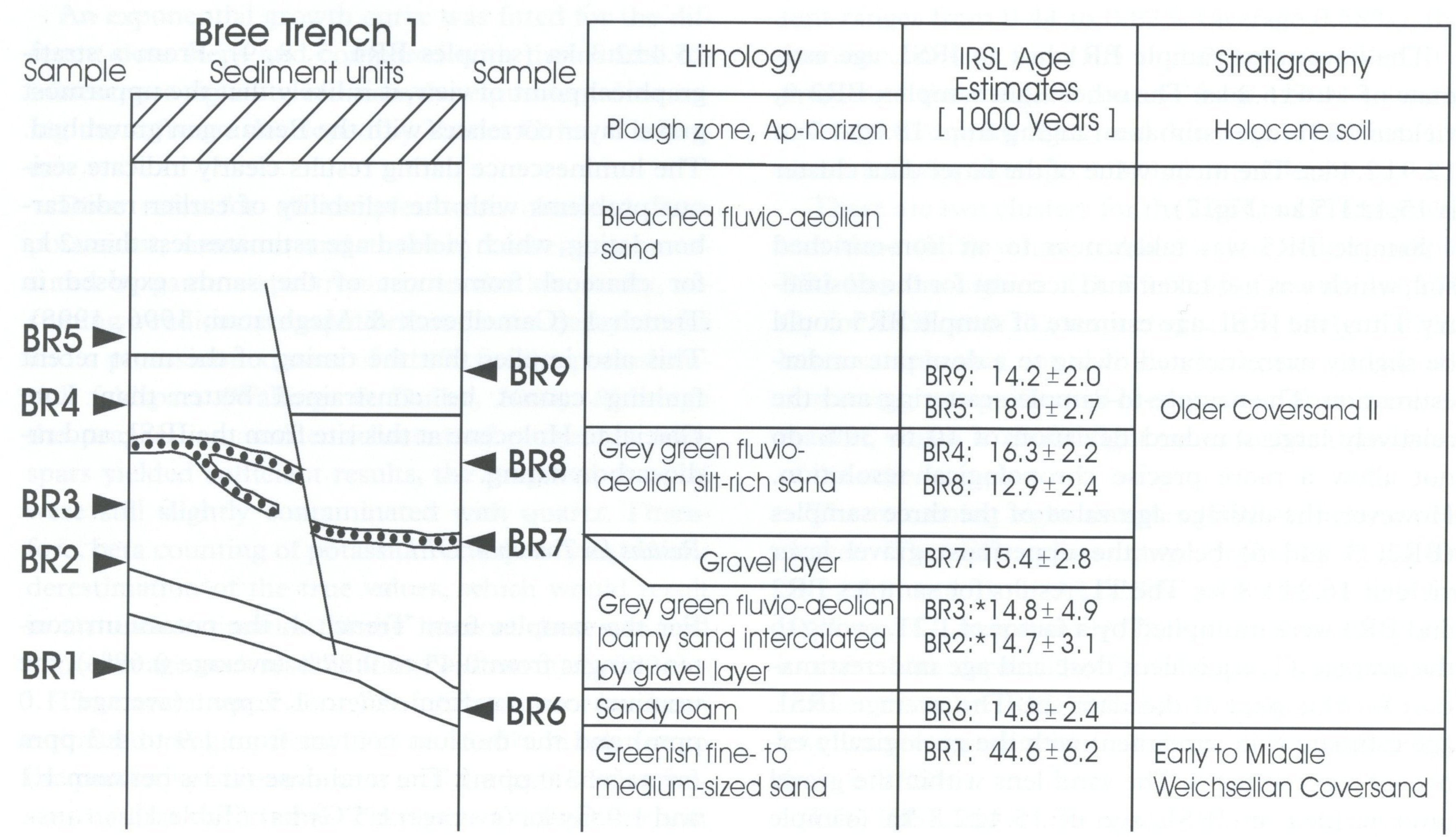

Fig. 7. Idealized lithology with sample positions and IRSL age estimates for Trench 1 ( ${ }^{\star}$ means TL age estimate). 
guished within the data set (Table 2). The lowermost sample, OPI1 a, has the highest ED values, $143 \pm 2$ and $175 \pm 30$ Gy for IRSL and TL, respectively. The ED values increase with depth from $33.8 \pm 2.3 \mathrm{~Gy}$ to $143.0 \pm 2.0 \mathrm{~Gy}$ and from $27.6 \pm 2.3$ to $175.2 \pm 29.7 \mathrm{~Gy}$ for the lowermost three samples (OPI6 and 3) for IRSL and TL, respectively. The IRSL equivalent dose values are $14-18 \%$ higher than those of the TL ED values for samples OPI6 and 3. The oldest sample OPI1a indicates an IRSL ED underestimation of $23 \%$. The uppermost five samples (OPI 5, 8, 9, 10 and 11) belong to a cluster with no ED increase with depth. The ED values range from $12.4 \pm 0.6$ to $19.1 \pm 2.5 \mathrm{~Gy}$ and from $12.7 \pm 0.7$ to $18.4 \pm 1.5 \mathrm{~Gy}$ for IRSL and TL, respectively. The differences between IRSL and TL are negligible for the uppermost five samples. It is likely that the sediment was wellbleached prior to deposition.

The IRSL age estimates of the four lowermost samples increase with depth from $12.0 \pm 1.6$ to $101 \pm 10$ ka. The uppermost four data points yield an IRSL age cluster ranging from $11.4 \pm 1.8$ to $6.8 \pm 1.2 \mathrm{ka}$. The average IRSL age estimate for these samples is $9.4 \pm 1.9$ $\mathrm{ka}$, or alternatively $10.3 \pm 1.0$, if sample OPI9 is excluded from the calculation.

\section{Discussion and chronological interpretation}

The existing chronostratigraphy of the coversand deposits in Belgium and the Netherlands (Vandenberghe, 1985) is based on a few radiocarbon and OSL age estimates. At the Lutterzand site in the Netherlands, a radiocarbon age of $27.5 \pm 0.25$ ka was determined on organic silt from a borehole section of the Beverborg Member underlying a gravel bed correlated with the Beuningen gravel layer (van Huissteden, 1990). The lateral equivalent of the Beuningen gravel bed yielded a radiocarbon age estimate of $19.1 \pm 0.18$ ka on humic extract of organics found in channel deposits (Bateman \& van Huissteden, 1999). However, the latter authors reported some uncertainties because the material is most likely reworked. The Older Coversands II, equivalent of the Lutterzand Member in the Dutch stratigraphy, covering the Beuningen gravel bed, yielded a radiocarbon age estimate of $14.5 \pm 0.15 \mathrm{ka} \mathrm{BP}$ on fruits from Potamogeton. However, Bateman \& van Huissteden (1999) stated that this radiocarbon age estimate may have been affected by the hardwater effect resulting in age overestimation. The Younger Coversand II and I, the Wierden Member in the Dutch stratigraphy, which is thought to be of Late Glacial age, cover the Older Coversand II. A radiocarbon age estimate of $12.93 \pm 0.21 \mathrm{ka} B P$ was determined for the Younger Coversand I (van Geel et al., 1989). The Younger Coversand II, most likely deposited during the Younger Dryas, yielded radiocarbon age estimates between 10.95 to $10.15 \mathrm{ka} \mathrm{BP}$ (Hoek, 1997). Most of the radiocarbon age estimates of the material from the Older Coversand II and older units have some dating uncertainties. Furthermore, the samples are from different sites for which a correlation is provided by lithological evidence only. Therefore, it is difficult to use the radiocarbon chronology for the Late Pleniglacial coversands as a reliable independent age control.

In a more recent study, Bateman \& van Huissteden (1999) determined seven OSL age estimates on monomineralic quartz from the coversands at the Lutterzand section. In this study, the Older Coversand I (Beverborg Member) yielded an age estimate of $21.9 \pm 1.9 \mathrm{ka}$ ( 1 data point); the Older Coversand II a mean OSL age estimate of $15.8 \pm 1.8 \mathrm{ka} \mathrm{BP}$ calculated on the base of four data points ranging from $17.6 \pm 2.6$ to $13.9 \pm 1.3 \mathrm{ka}$ BP. The Younger Coversands II and I had a mean OSL age estimate of $12.5 \pm 1.1 \mathrm{ka}$ $\mathrm{BP}$, which was calculated on the base of two data points ranging from $13.3 \pm 0.9$ to $11.7 \pm 1.5 \mathrm{ka} B P$.

In the present study, a comparison of radiocarbon, IRSL and TL age estimates was carried out on sediment from identical coversand layers in the same section. Most of these IRSL age estimates are in agreement with independent chronologies. However, IRSL age underestimation owing to unknown methodological reasons, as described in the literature (Wallinga \& Duller, 2000), cannot be excluded.

The influence of the natural moisture and the internal potassium content of potassium-rich feldspars on dose rate calculation and luminescence age estimates are presented in tables 3 to 5 for sample OPI1a. The moisture was estimated for all samples based on the present level of the water table and the porosity of the sediment. A natural moisture of $25 \%$ and an internal $\mathrm{K}$ content of $9 \pm 1 \%$ were estimated for the age calculation of sample OPI la (tables 1 and 2).

The maximum dose rate alteration based on the two extremes indicates a hypothetical maximum luminescence age underestimation of $12 \%$ and/or luminescence age overestimation of $30 \%$ for sample OPI $1 \mathrm{a}$, if compared with the applied value of $25 \pm 5 \%$ and $9 \pm 1 \%$ for moisture and potassium content. These calculations have only hypothetical character and do not exclude potential systematic underestimation owing to unknown methodological reasons, as described in the literature!

The TL results indicate systematic age underestimation up to $20 \%$ for the Older and Younger Coversands in Trench 1 . However, the results from Trench 
4 do not confirm the results from Trench 1 concerning TL age underestimation. At present, it is unclear whether methodological reasons cause these differences (e.g. optical absorption), or weathering of the mineral surface, or too few data points.

In this study, the IRSL and TL age calculations have been slightly altered resulting in age differences between 5 and 30\% compared to the preliminary results presented in a previous study (Vanneste et al., 2001). The alterations were necessary owing to background subtraction for the determination of the IRSL equivalent dose values and better estimates for the natural moisture and the internal potassium content of the potassium-rich feldspars. The chronostratigraphic interpretation of the coversand units remains in general the same. The IRSL age estimates from Trench 1 indicate two age clusters. It is likely that the lowermost sand layer (BR1) was deposited during the Middle Weichselian, although an age overestimation

Table 3: Influence of moisture ( $\mathrm{H} 2 \mathrm{O}$ weight \%) on dose rate calculated for sample OPI1a with an internal potassium content of $9 \pm 1 \%$.

\begin{tabular}{lll}
\hline $\begin{array}{l}\text { Moisture } \\
{[\text { weight \%] }}\end{array}$ & $\begin{array}{l}\text { Dose rate } \\
{[\mu \mathrm{Gy} / \mathrm{a}]}\end{array}$ & $\begin{array}{l}\text { Dose rate alteration } \\
{[\%]}\end{array}$ \\
\hline 10 & 1621 & +15 \\
15 & 1550 & +10 \\
20 & 1479 & +5 \\
25 & 1411 & $\sim 0$ \\
30 & 1344 & -5 \\
35 & 1278 & -10 \\
\hline
\end{tabular}

Table 4: Influence of the internal potassium content on the dose rate calculated for sample OPI 1 a and a moisture content of $25 \pm 5 \%$.

\begin{tabular}{lll}
\hline $\begin{array}{l}\text { Potassium content } \\
{[\%]}\end{array}$ & $\begin{array}{l}\text { Dose rate } \\
{[\mu \mathrm{Gy} / \mathrm{a}]}\end{array}$ & $\begin{array}{l}\text { Dose rate alteration } \\
{[\%]}\end{array}$ \\
\hline 8 & 1369 & -3 \\
9 & 1411 & $\sim 0$ \\
10 & 1453 & +3 \\
11 & 1495 & +6 \\
12 & 1538 & +9 \\
13 & 1580 & +12 \\
14 & 1622 & +15 \\
\hline
\end{tabular}

Table 5: Maximum influence of internal potassium content and moisture on the dose rate determination for sample OPI1a.

\begin{tabular}{|c|c|c|c|}
\hline $\begin{array}{l}\text { Potassium } \\
\text { content } \\
{[\%]}\end{array}$ & $\begin{array}{l}\text { Moisture } \\
\text { [\%] }\end{array}$ & $\begin{array}{l}\text { Dose rate } \\
{[\mu \mathrm{Gy} / \mathrm{a}]}\end{array}$ & $\begin{array}{l}\text { Dose rate } \\
\text { alteration } \\
{[\%]}\end{array}$ \\
\hline 8 & 35 & 1236 & -12 \\
\hline 9 & 25 & 1411 & $\sim 0$ \\
\hline 14 & 10 & 1832 & +30 \\
\hline
\end{tabular}

owing to insufficient bleaching of the sand prior to deposition cannot be excluded, as evidenced by the very high TL age estimate.

The sediment is intercalated with two gravel layers. It is likely that the uppermost gravel layer corresponds with the Beuningen gravel bed. However, the resolution of the IRSL dating method is not high enough to distinguish deposition ages between the sand layers below and above the gravel layer. The age estimates do not indicate a significant hiatus. The average IRSL age estimate for the samples below the uppermost gravel layer is $16.8 \pm 1.8 \mathrm{ka}$, a sand-lens from within the gravel layer yielded $15.4 \pm 2.8 \mathrm{ka}$ and the samples from above the gravel layer yielded IRSL age estimates from $15.4 \pm 2.3 \mathrm{ka}$.

It is most likely that the sediment above the upper gravel horizon was synchronously deposited with the Older Coversand II, alternatively the Younger Coversand I.

Four luminescence age clusters were determined for the reworked coversand layers in Trench 4. The lower reworked cover sand unit has an IRSL age estimate of $101 \pm 10 \mathrm{ka}$ indicating a Saalian ('Dilsen formation', according to Beerten et al., 1999), if IRSL age underestimation is assumed, or Early Weichselian deposition age. The reworked coversand between the two reddish tongue-like layers yielded an IRSL age estimate of $69.9 \pm 9.0 \mathrm{ka}$ ('Saint Lenards Formation'), which is not in agreement with the radiocarbon age estimates on organic material from the same horizon (Fig. 8). A significant radiocarbon age underestimation is most likely owing to the upper age limit of this method or a contamination with modern $\mathrm{C}$ and by the large ${ }^{14} \mathrm{C}$ variation for this layer. Alternatively, the sediment may not have been sufficiently exposed to sunlight prior to deposition, hence resulting in IRSL and TL age overestimation.

The reworked coversand above the red tongues is significantly younger. The lower part of the unit yielded IRSL age estimates of $22.2 \pm 2.5$ and $12.0 \pm 1.6 \mathrm{ka}$, indicating a late Weichselian deposition age ("Wildert formation'). It is likely that also in Trench 4 the erosional gravel bed was deposited synchronously with the fluvial and niveo-fluvial gravel after the last glacial maximum, which is correlated with the Beuningen gravel bed horizon. This is in good agreement with the major period of erosion recorded in the loess record at about $17 \mathrm{ka} \mathrm{BP}$, as evidenced in the loess/palaeosol sequences of the Middle Rhine area and in NW Belgium (Boenigk \& Frechen, 2001; Frechen et al., 2001).

The IRSL dating of the upper loamy coversands resulted in age estimates between $11.4 \pm 1.8$ to $6.8 \pm 1.2$ $\mathrm{ka}$. It is likely that this uppermost unit corresponds to 


\begin{tabular}{|c|c|c|c|c|c|}
\hline Sediment units & \multirow[t]{2}{*}{ Sample } & Lithology & C-14 Age Estimates & IRSL Age Estimates & Stratigraphy \\
\hline BPEPEPA & & Ap-horizon & & & Holocene soil \\
\hline 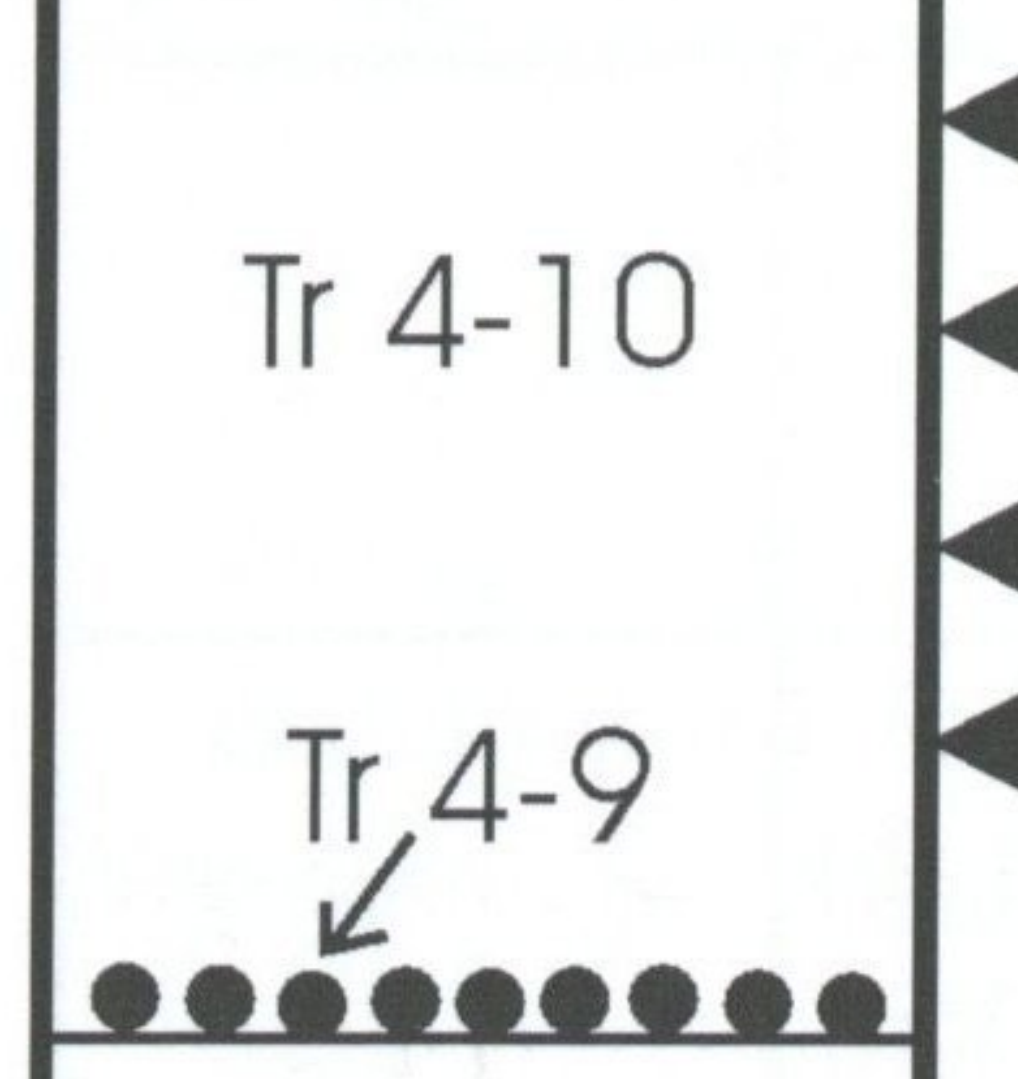 & \begin{tabular}{l|l}
$\mathrm{Pl}$ & 1 \\
$\mathrm{Pl}$ & 9 \\
$\mathrm{Pl}$ & 8 \\
$\mathrm{Pl}$ & $1 \mathrm{C}$
\end{tabular} & $\begin{array}{l}\text { Silt-rich fine-grained } \\
\text { Sand intercalated by } \\
\text { a few mono-pebble } \\
\text { beds } \\
\text { Gravel bed }\end{array}$ & $\begin{array}{r}10.5-10.2 \mathrm{ka} \mathrm{cal} \mathrm{BP} \\
13.2-12.7 \mathrm{ka} \mathrm{cal} \mathrm{BP} \\
3.5-3.3 \mathrm{ka} \mathrm{cal} \mathrm{BP}\end{array}$ & $\begin{array}{r}9.6 \pm 1.9 \mathrm{ka} \\
6.8 \pm 1.2 \mathrm{ka} \\
11.4 \pm 1.8 \mathrm{ka} \\
9.9 \pm 1.1 \mathrm{ka}\end{array}$ & $\begin{array}{l}\text { Younger coversands I } \\
\text { Older coversands ॥ }\end{array}$ \\
\hline $\operatorname{Tr} 4-8$ & $\begin{array}{ll}5 \\
\mathrm{Pl}\end{array}$ & $\begin{array}{l}\text { Reworked coversand, } \\
\text { Laminated, silt-rich } \\
\text { fine-grained sand, inter } \\
\text { calated gravel beds } \\
\text { and soil material } \\
\end{array}$ & & $\begin{array}{l}12.0 \pm 1.6 \mathrm{ka} \\
22.2 \pm 2.5 \mathrm{ka}\end{array}$ & Older coversands I \\
\hline $\operatorname{Tr} 4-6$ & PI 3 & $\begin{array}{l}\text { Silt-rich fine- to } \\
\text { medium grained sand } \\
\text { interminglad by fine } \\
\text { gravel } \\
\text { Solifluction } \\
\end{array}$ & $\begin{array}{l}15.5-13.5 \mathrm{ka} \mathrm{cal} \mathrm{BP} \\
26.1 \pm 0.3 \mathrm{ka} \mathrm{BP} \\
30.5 \pm 0.5 \mathrm{ka} \mathrm{BP} \\
39.1 \pm 1.4 \mathrm{ka} \mathrm{BP}\end{array}$ & $69 \pm 9 \mathrm{ka}$ & $\begin{array}{l}\text { Early to Middle } \\
\text { Weichselian coversands }\end{array}$ \\
\hline $\operatorname{Tr} 4-4 \mathrm{E}$ & $1 \mathrm{c}$ & $\begin{array}{l}\text { Reworked fine-grained } \\
\text { sand intercalated by } \\
\text { silt-rich lenses }\end{array}$ & & $101 \pm 10 \mathrm{ka}$ & $\begin{array}{l}\text { Saalian/ } \\
\text { Early Weichselian } \\
\text { coversands }\end{array}$ \\
\hline
\end{tabular}

Fig. 8. Idealized lithology with sample positions and IRSL age estimates for Trench 4 . The ${ }^{14} \mathrm{C}$ age estimates are from Vanneste et al. (2001).

the Younger Coversands I or II ranging from Late Glacial to early Holocene. If the youngest data point is excluded, IRSL and radiocarbon age estimates are in agreement (Fig. 8). The average IRSL age estimate indicates an Early Holocene deposition age or a deposition during the Younger Dryas ('Hechtel formation'). The latter interpretation favours correlation with the Younger Coversand I or II. The sediments of the 'Hechtel formation', according to Beerten et al. (1999), consist mainly of dune sands. In the study area, the uppermost layer of silt-rich fine-grained sand intercalated by a few mono-pebble beds appears to correlate with the 'Hechtel formation'.

\section{Conclusions}

In summary, the chronological results indicate that at least five aeolian/fluvio-aeolian sediment units are exposed in the investigated sections along the Bree fault scarp (Fig. 9).

The oldest coversand accumulated during the late Saalian or Early Weichselian, followed by coversand deposited during the Early or Middle Weichselian and, in Trench 1, during the Middle Weichselian. Several sediment units can be distinguished within the Late Weichselian. The sediments below the gravel lay- ers in Trench 1 and Trench 4 yielded an average IRSL age estimate of $16.8 \pm 1.8 \mathrm{ka}$, which is in agreement with the stratigraphical correlation with the top of the Older Coversand I. The overlying gravel layer is correlated with the Beuningen gravel layer. In Trench 1, the sands just above this gravel layer bed have a deposition age of $15.4 \pm 2.3 \mathrm{ka}$ and are correlated with the Older Coversand II. The uppermost coversand unit in Trench 4 is correlated with the Younger Coversand II or I.

The present data set does not support a systematic IRSL age underestimation for potassium-rich feldspar as described in earlier publications. Furthermore, the new IRSL dating of the coversand deposits in NE Belgium provides a more reliable chronological framework for at least five earthquake events that are inferred to have occurred since the deposition of the oldest sampled coversand unit in Trench 4 , as discussed in more detail by Vanneste et al. (2001).

\section{Acknowledgments}

This study is part of the PALEOSIS project funded by the European Commission (ENV4-CT97-0578). We thank Ernst Ardelean, Regensburg, for the high 


\begin{tabular}{|c|c|c|c|c|c|c|c|c|}
\hline \multirow[t]{2}{*}{ Stratigraphy } & \multicolumn{4}{|c|}{$\begin{array}{l}\text { Age Estimates in } 1000 \text { years } \\
\text { Bateman \& van Huissteden (1999) }\end{array}$} & \multicolumn{4}{|c|}{$\begin{array}{l}\text { Age Estimates in } 1000 \text { years } \\
\text { This study }\end{array}$} \\
\hline & ${ }^{14} \mathrm{C}$ uncal. & ${ }^{14} \mathrm{C}$ cal. & OSL & Average OSL & ${ }^{14} \mathrm{C}$ uncal. & ${ }^{14} \mathrm{C}$ cal. & IRSL & Average IRSL \\
\hline $\begin{array}{l}\text { Younger Difftsand } \\
\text { Holocene Soil }\end{array}$ & $7.54 \pm 0.05$ & $<1.0$ & $0.6 \pm 0.1$ & & & & & \\
\hline $\begin{array}{l}\text { Younger Coversand II } \\
\text { and } \\
\text { Younger Coversand I }\end{array}$ & $\begin{array}{l}10.55 \pm 0.40 \\
12.90 \pm 0.21\end{array}$ & $15.3-11.8$ & $\begin{array}{l}13.3 \pm 0.9 \\
11.7 \pm 1.5\end{array}$ & $12.5 \pm 1.1$ & & $\begin{array}{l}10.5-10.2 \\
13.2-12.7\end{array}$ & $\begin{array}{c}9.6 \pm 1.9 \\
(6.8 \pm 1.2) \\
11.4 \pm 1.8 \\
9.9 \pm 1.1\end{array}$ & $10.3 \pm 1.0$ \\
\hline Older Coversand II & $14.0 \pm 0.15$ & $16.8-15.3$ & $\begin{array}{l}17.6 \pm 2.6 \\
16.1 \pm 1.9 \\
13.9 \pm 1.3\end{array}$ & $15.8 \pm 1.8$ & & & 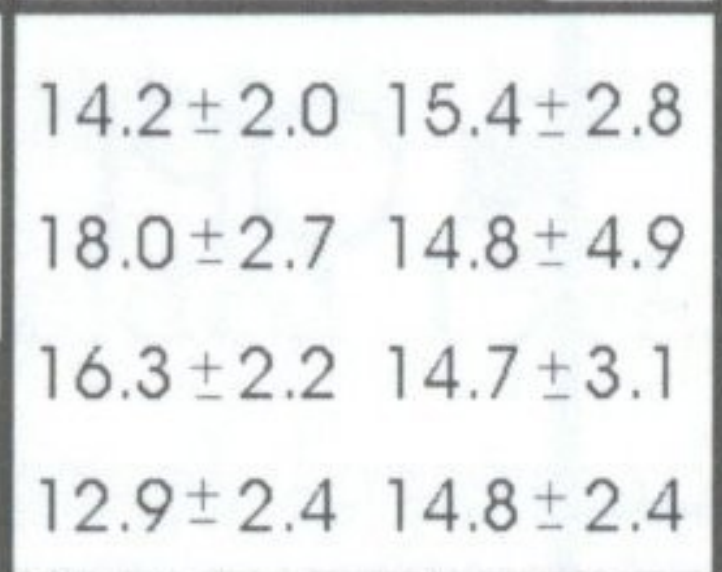 & $15.1 \pm 1.5$ \\
\hline Older Coversand I & $\begin{array}{l}19.1 \pm 0.18 \\
27.5 \pm 0.25\end{array} \mid$ & $30.5-22.5$ & $21.9 \pm 1.9$ & & & & $\begin{array}{c}(12.0 \pm 2.5) \\
22.2 \pm 2.5\end{array}$ & \\
\hline $\begin{array}{l}\text { Early to Middle } \\
\text { Weichselian Coversand }\end{array}$ & & & & & $\begin{array}{l}26.1 \pm 0.3 \\
30.5 \pm 0.5 \\
39.1 \pm 1.4\end{array}$ & & $\begin{array}{l}44.6 \pm 6.2 \\
69.9 \pm 9\end{array}$ & \\
\hline $\begin{array}{l}\text { Early Weichselian/ } \\
\text { Saalian Coversand }\end{array}$ & & & & & & & $101 \pm 10$ & \\
\hline
\end{tabular}

Fig. 9. Summary of radiocarbon and luminescence age estimates available for the deposition history of the coversands in the Netherlands and Belgium.

quality computer diagrams and Frank Chambers, Cheltenham, for valuable comments on an earlier version of the manuscript.

\section{References}

Balescu, S. \& Lamothe, M., 1992. The blue emission of Kfeldspars coarse grains and its potential for overcoming TL age underestimation. Quaternary Science Reviews 11:45-51.

Bateman, M.D. \& van Huissteden, K., 1999. The timing of lastglacial periglacial and aeolian events, Twente, eastern Netherlands. Journal of Quaternary Science 14: 277-283.

Beerten, K., Vandenberghe, N., Gullentops, F. \& Paulissen, E., 1999. Technisch verslag bij de Quartairkaart van België, Vlaams Gewest, kaartblad Maaseik (18), Ministerie van de Vlaamse Gemeenschap, Administratie Natuurlijke Rijkdommen en Energie, Brussel.

Boenigk, W. \& Frechen, M., 2001. The loess record in sections at Koblenz-Metternich and Tönchesberg in the Middle Rhine area. Quaternary International 76/77: 201-209.

Camelbeeck, T. \& Meghraoui, M., 1996. Large earthquakes in northern Europe more likely than once thought.- EOS, Transaction American Geophysical Union 77: 405 and 409.

Camelbeeck, T. \& Meghraoui, M., 1998. Geological and geophysical evidence for large palaeo-earthquakes with surface faulting in the Roer Graben (northwest Europe). Geophysical Journal International 132: 347-362.

Dijkmans, J.W.A. \& Wintle, A.G., 1991. Methodological problems in thermoluminescence dating of Weichselian coversand and late Holocene drift sand from the Lutterzand area, E. Netherlands. Geologie en Mijnbouw 70: 21-33.

Dijkmans, J.W.A., van Mourik, J.M. \& Wintle, A.G., 1992. Ther- moluminescence dating of aeolian sands from polycyclic soil profiles in southern Netherlands. Quaternary Science Reviews 11: 85-92.

Dijkmans, J.W.A., Wintle, A.G. \& Mejdahl,V., 1988. Some thermoluminescence properties and dating of eolian sands from the Netherlands. Quaternary Science Reviews 7: 349-355.

Frechen, M., 1995. Lumineszenz-Datierungen der pleistozänen Tierfährten von Bottrop-Welheim. Münchner Geowissenschaftliche Abhandlungen 27: 63-80.

Frechen, M., Dermann, B., Boenigk, W. \& Ronen, A., 2001. Luminescence chronology of aeolianites from the section at Givat Olga - Coastal Plain of Israel. Quaternary Science Reviews 20: 805-809.

Frechen, M. \& van den Berg, M.W., in press. The coversands and timing of Late Quaternary Earthquake events along the Peel Boundary Fault in the Netherlands. Geologie en Mijnbouw, 81 (1), 2002.

Frechen, M., van Vliet-Lanoë, B., Vandenhaute, P., 2001. The Upper Pleistocene loess record at Harmignies/Belgium - high resolution terrestrial archive of climate forcing. Palaeogeography Palaeoclimatology Palaeoecology (173: 175-195).

Hoek, W., 1997. Palaeogeography of Late glacial vegetations. PhD thesis, Vrije Universiteit, Amsterdam, 147 pp.

Paulissen, E., 1983. Les nappes alluviales et les failles quaternaires du Plateau de Campine.- In: Robaszynski, F. \& Dupuis, C. (eds.), Guides Géologiques Régionaux: Belgique, Masson, Paris, pp. 167-170.

Smith, B.W., Rhodes, E.J., Stokes, S., Spooner, N.A. \& Aitken, M.J., 1991. Optical dating of sediments: initial quartz results from Oxford. Archaeometry 32: 19-31.

Stokes, S., 1991. Quartz-based optical dating of Weichselian coversands from the eastern Netherlands. Geologie en Mijnbouw 70: 327-337.

Vandenberghe, J., 1985. Palaeoenvironment and stratigraphy dur- 
ing the last glacial in the Belgian-Dutch border region. Quaternary Research 24: 23-38.

Van Geel, B., Coope, G.R. \& Van der Hammen, T., 1989. Palaeoecology and stratigraphy of the Lateglacial type section at Usselo (The Netherlands). Review of Palaeobotany and Palynology 60: 25-130.

Van Huissteden, J., 1990. Tundra rivers of the Last Glacial: sedimentation and geomorphological processes during the Middle Pleniglacial in the Dinkel valley (eastern Netherlands). Mededelingen Rijks Geologische Dienst 44: 3-138.

Vanneste, K., Meghraoui, M. \& Camelbeeck T., 1999. Late Quaternary earthquake-related soft-sediment deformation along the Belgian portion of the Feldbiss Fault, Lower Rhine Graben system. Tectonophysics 309: 57-79.
Vanneste, K., Verbeeck, K., Camelbeeck, T., Renardy, F., Jongmans, D., Meghraoui, M., Paulissen, E. \& Frechen, M., 2001. Surface rupturing history of the Bree fault escarpment, Roer Valley Graben: new trench evidence for at least six successive events during the last 150 to $185 \mathrm{kyr}$. Journal of Seismology, 5: 329359.

Wallinga, J. \& Duller, G.A.T., 2000. The effect of optical absorption on the infrared stimulated luminescence age obtained on coarse-grain feldspar. Quaternary Science Reviews 19: 10351042.

Wintle, A.G., 1973. Anomalous fading of thermoluminescence in mineral samples. Nature 245: 143-144.

Wintle, A.G. \& Duller, G.A.T., 1991. The effect of optical absorption on luminescence dating. Ancient TL 9: 37-39. 